NBER WORKING PAPER SERIES

\title{
TRADE POLICY UNCERTAINTY AND EXPORTS: EVIDENCE FROM CHINA'S WTO ACCESSION
}

\author{
Ling Feng \\ Zhiyuan Li \\ Deborah L. Swenson \\ Working Paper 21985 \\ http://www.nber.org/papers/w21985
NATIONAL BUREAU OF ECONOMIC RESEARCH
1050 Massachusetts Avenue
Cambridge, MA 02138
February 2016

We thank Robert Staiger, Robert Feenstra, Andres Rodriguez-Clare, Thibault Fally, Ben Faber, Jiandong $\mathrm{Ju}$, Peter Morrow, Linke Zhu, two anonymous referee, seminar participants at University of California, Berkeley, University of California, Davis, Tsinghua University, University of Nottingham Ningbo China and conference participants at 11th FREIT-LETC for helpful comments. Ling Feng and Zhiyuan Li thank the National Natural Science Foundation of China for financial support through Grant No. 71403159 and No. 71203128, respectively. Zhiyuan Li thanks the Economics Department at the University of California, Berkeley, where he was a Visiting Scholar during the writing of this paper. The views expressed herein are those of the authors and do not necessarily reflect the views of the National Bureau of Economic Research.

NBER working papers are circulated for discussion and comment purposes. They have not been peerreviewed or been subject to the review by the NBER Board of Directors that accompanies official NBER publications.

(C) 2016 by Ling Feng, Zhiyuan Li, and Deborah L. Swenson. All rights reserved. Short sections of text, not to exceed two paragraphs, may be quoted without explicit permission provided that full credit, including $(\subset)$ notice, is given to the source. 
Trade Policy Uncertainty and Exports: Evidence from China's WTO Accession

Ling Feng, Zhiyuan Li, and Deborah L. Swenson

NBER Working Paper No. 21985

February 2016

JEL No. F13,F14,F23

\begin{abstract}
$\underline{\text { ABSTRACT }}$
This paper studies how reduction in trade policy uncertainty affects firm export decisions. Using a firm-product level dataset on Chinese exports to the United States and the European Union in the years surrounding China's WTO accession, we provide strong evidence that reduction in trade policy uncertainty simultaneously induced firm entries to and firm exits from export activity within fine product-level markets. In addition, we uncover accompanying changes in export product prices and quality that coincided with this reallocation: firms that provided higher quality products at lower prices entered the export market, while firms that had higher prices and provided lower quality products prior to the changes, exited. To explain the simultaneous export entries and exits, as well as the change in product export prices and quality induced by trade policy uncertainty changes, we provide a model of heterogeneous firms which incorporates trade policy uncertainty, tracing the effects of the changes in policy uncertainty on firm-level payoffs and the resulting selection effects which apply to new entrants and incumbents.
\end{abstract}

Ling Feng

School of Finance

Shanghai University of Finance

and Economics

777 Guoding Road

Shanghai, China, 200433

feng.ling@mail.shufe.edu.cn

Zhiyuan Li

School of Economics

Shanghai University of Finance

\& Economics

777 Guoding Road

Shanghai, P.R. China. 200433

zhyli97@gmail.com
Deborah L. Swenson

Department of Economics

University of California, Davis

Davis, CA 95616

and NBER

deswenson@ucdavis.edu 


\section{Introduction}

This paper studies how trade policy uncertainty affects firm export decisions. In particular, we study the micro firm-level response margins which shaped firm export changes following changes in trade policy uncertainty. To answer these questions, we take advantage of the trade activities of Chinese firms that exported to the United States at the time of China's 2001 WTO entry. ${ }^{1}$

Three factors make this setting especially suitable for addressing our question. First, Chinese exports to the United States during this period were characterized by strong dynamics. As Figure 1 shows, the exceptional acceleration of China's export growth coincided almost exactly with China's WTO entry. More important, as we show in detail in section 2, there was remarkable reallocation of export activities across firms. Firms who exited the export market between 2000 and 2006 were responsible for 76 percent of China's total export value just prior to China's WTO accession. Indeed, while some of the reallocation led to market share expansion by established exporters, new exporters who started to export following China's WTO entry were responsible for 67 percent of China's export activity in 2006.

Second, China's WTO entry provided exporters with a substantial reduction in trade policy uncertainty in the U.S. market. Such uncertainty reduction stems from the small bound duties in the U.S. that are negotiated under Most Favored Nation (MFN) treatment. As MFN binds the applied duties by these bound rates, the MFN bound rates provide a significant reduction in the gap between the applied rate and the bound rate. China's WTO accession thus removed the threat that the U.S. might at some future time revoke its Most Favored Nation treatment of China's exports, reverting instead to the much higher general tariff rates levied by the U.S. on non-MFN countries.

Third, the United States is one of the most important markets for Chinese exporters. For firms that ever exported to the US during the 2000 to 2006 interval, 25\% of their export value was shipped to the United States, followed by $18 \%$ to the European Union and $12 \%$ to Japan.

\footnotetext{
${ }^{1}$ Prior to China's WTO entry each of its trade partners was free to decide whether to provide China access to their MFN treatment. MFN status for China, which was suspended in 1951 by the United States, was restored in 1980, though its continuation was subject to annual extensions. Following 1989, the annual renewal of China's MFN status became a source of considerable debate in the U.S. Congress (Dumbaugh, 2001).
} 
Analysis of China's exports to the U.S. reveals a number of robust links between trade policy uncertainty reduction and firm exports. First, we find that trade volume growth associated with new export entry was positively related to product-level uncertainty reduction following from China's WTO accession. These product level responses to uncertainty reduction were apparent by 2002 and grew in magnitude over the longer horizon. More importantly, we also find a positive relationship between the degree of trade policy uncertainty reduction and exits by some of the incumbent firms that were engaged in U.S. export prior to the policy changes.

To understand why trade policy uncertainty reduction induced export entry by one group of firms while it caused another group of firms to exit, we compare the export characteristics of new exporters with the characteristics of exiters. ${ }^{2}$ We find strong evidence that new exporters charged lower prices while they exported higher quality goods than did exiting firms. ${ }^{3}$ Moreover, we find that the advantages of new exporters relative to exiting exporters were larger for products that experienced larger reductions in trade policy uncertainty.

Our discovery of simultaneous export entry and export exit at the product-level are not initially intuitive. In particular, it is commonly assumed that lower tariff uncertainty, which facilitates entry by new exporters, will also benefit, or at worst be harmless to incumbents in the export market. Consequently heterogeneous firm models, such as Melitz (2003) and Melitz and Ottaviano (2008), do not predict an increase in the exit from export by some exporting incumbents following favorable trade policy developments. In other words, while trade liberalization expands export opportunities and induces export entry, these models do not predict that trade liberalization will also cause some incumbents to exit the export market.

Nonetheless, recent work on the effects of trade liberalization, demonstrates the value of modelling and evaluating effects stemming from the reallocation of activities across firms and products. For example, Mayer, Melitz and Ottaviano (2014) consider how changes in export competition lead to changes in product export composition, with consequences for firm-level productivity, while Melitz and Redding (2013) demonstrate how endogenous firm selection has the potential to influence aggregate productivity.

\footnotetext{
${ }^{2}$ The term "new exporter" refers to a firm that was not involved in export in 2000, but exported in one of the years following China's WTO accession. The export "exiters" are defined as firms that exported to the US in 2000 but ceased their US export following China's WTO accession. Further details about the definitions are provided in Section 2.

${ }^{3}$ Product quality is measured following Khandelwal, Schott and Wei (2013).
} 
To explain the simultaneous entries by new exporters and exits by incumbent firms, we provide a parsimonious extension of Melitz (2003) which incorporates trade policy uncertainty in a setting where congestion effects influence the cost of export. In particular, our model demonstrates how trade policy uncertainty reduction, which lowers firm expectations about the level of tariff payments, encourages export entry due to the expectation of increased export profits. In turn, as an increasing mass of firms seek to serve the export market, congestion externalities raise the per-period fixed costs of export which are tied to export support such as logistics, finance, and ongoing advertising (see Bergin and Lin (2012)). Ultimately, as congestion externalities raise the fixed costs of export, and therefore the cutoff productivity for export, lower productivity incumbent firms whose productivity falls short of the new export productivity thresholds cease to export. Nonetheless, while the lowest productivity exporters may be driven out of the market due to rising cutoff levels, the total number of exporting firms may increase through the fresh export entry by firms lured to export by the improved trade policy environment.

By demonstrating a connection between reductions in trade policy uncertainty and firm export activities, our work adds to the recent literature on trade policy uncertainty and international trade, pioneered by Handley (2014) and Handley and Limao (2014a, 2014b). ${ }^{4}$ Our paper is closest to Handley and Limao (2014b) which also studies the effects of trade policy uncertainty reductions on China's U.S.-destined exports and the welfare implication for US consumers. However, while Handley and Limao (2014b) focuse on export growth changes at the product-level, our study provides insights on the diverse changes within products which are tied to firm-level decisions within industries. Notably, our work is the first to document and explain the simultaneous entry and exit responses which stem from trade policy uncertainty reduction. ${ }^{5}$

\footnotetext{
${ }^{4}$ Another type of uncertainty, market-specific demand uncertainty, has been studied in the literature. For example, in a partial equilibrium representative firm setting, Conconi, Sapir and Zanardi (2013) studies how demand uncertainty in a foreign market leads firms to experiment with exports before engaging in FDI. In a heterogeneous though still partial equilibrium setting, Nguyen (2012) shows how demand uncertainty may cause firms to delay exporting in order to gather information about foreign demand and to use previous demand realizations to forecast unknown levels of demand in as yet untested destinations. In contrast, our analysis of trade policy uncertainty focuses on the simultaneous entry and exit of firms in the same market which crucially hinges on general equilibrium conditions.

${ }^{5}$ Khandelwal, Schott and Wei (2013) also show that following the removal of quotas on Chinese textile and clothing exports in 2005, high-productivity new entrants entered the export market with relatively low prices as they replaced low-productivity firms who exported high-priced exports. However, their explanation, the removal of inefficient institutional arrangements, favored a subset of firms who were active in quota-limited industries, while our results extend to a period several years before the final removal of quota system and extends to other industries that did not experience similar changes in quota treatment.
} 
Our main finding - that Chinese firm export responses involve reallocation through simultaneous entries and exits - also supports recent work in international trade that shows the effects of trade policy changes are often observed on the extensive margin. ${ }^{6}$ Indeed, by tracking the margins of China's export changes associated with China's WTO accession, including shifts in export activity from low-quality high-price exiters to highquality low-price new exporters, our paper also contributes to the understanding of resource reallocations induced by trade liberalization. While the current literature, (e.g., Melitz (2003) and Melitz and Ottaviano (2008)) sheds light on the resource reallocation between domestic firms and exporting firms, our study identifies an additional margin as it shows how decreases in trade policy uncertainty can lead to reallocation towards more productive newcomers and away from less productive exiting exporters. ${ }^{7}$ The reallocation effects we observe are also similar to the reallocation effects uncovered in Alfaro and Chen's (2015) work on FDI spillovers, due to the role for selection effects. ${ }^{8}$ The characteristics of new exporters and exiters we document in our work are also consistent with the observations of Chinese export prices in Mandel (2013) which studies how competition from Chinese exporters affected the mark-ups and marginal costs of other exporters who shipped their products to the U.S.

Finally, our paper also contributes to the literature that seeks to understand how changes in trade policy have influenced U.S. economic outcomes. The relevance of this issue is made apparent by the work of Autor, Dorn and Hanson (2013), and Autor, Dorn, Hanson and Song (2014), both of which show how increased imports from China affected U.S. labor markets. In addition, Pierce and Schott (2013) find that the uncertainty reduction associated with China's WTO accession can help explain changes in U.S. manufacturing employment and wages. Indeed, our results suggest that the unusually strong downturn in the U.S. manufacturing labor market noted by Pierce and Schott (2013) may have been driven not only by the growth in overall exports that followed the trade policy uncertainty reduction, but also by the intensification of product market competition in the U.S. stemming from the exits of less capable Chinese exporters and the entry of higher-quality and higher-capability exporting firms.

\footnotetext{
${ }^{6}$ For example, Debaere and Mostashari (2010) provide evidence that extensive margin responses to U.S. tariff policy changes had an effect on U.S. country-product imports.

${ }^{7}$ A growing strand of macroeconomics literature, including Ghironi and Melitz (2005), Alessandria and Choi (2007) and Ruhl and Willis (2014), study firms' entry and export decisions in business cycles through the lens of dynamic, stochastic general equilibrium (DSGE) models.

${ }^{8}$ Alfaro and Chen (2015) discover that increases in aggregate productivity following FDI are due to between-firm selection effects which lead to the exit of the least productive firms in addition to the beneficial within firm productivity spillovers which enhance the productivity of ongoing firms.
} 
The rest of the paper is organized as follows. Section 2 discusses the salient features of Chinese export dynamics between 2000 and 2006, and introduces the key policy developments tied to China's WTO accession. Section 3 provides a model which helps to explain the developments of this period, explaining the mechanism through which trade policy uncertainty reductions may induce simultaneous entries and exits. Section 4 introduces the data and presents our empirical results regarding the impacts of uncertainty reductions on firms' entry and exit decisions. Section 5 further examines the impact of uncertainty reduction as manifested by the intensification of market competition. Section 6 concludes.

\section{Background: Aggregate Reallocation and Trade Policy Uncertainty}

In this section, we document two stylized facts that are potentially linked. The first notable feature was a dramatic reallocation of export activities across firms following China's WTO accession, largely due to shifts in export value tied to extensive margin of export entries and exits. The second observation is that China's WTO entry provided exporters with a substantial reduction in trade policy uncertainty. In succeeding sections, we will examine whether the aggregate reallocations can be explained by the reductions in trade policy uncertainty.

\subsection{Aggregate Reallocation}

To provide information on the export dynamics in China's 2000 to 2006 U.S. exports, we decompose changes according to the margins of adjustment. Throughout the paper, we define four margins of adjustment: "exiters", "incumbents", "new exporters" and "adders". The "new exporters" and "adders" are summed together to form the aggregate we term, "new entrants". For each year $t$ after WTO accession ( $t=2002$ through 2006), the margins of "exiters", "incumbents", and "new entrants" are defined respectively as the firm*product combinations that were exported to the US in 2000 but not in year $t$, that were exported both in 2000 and in year $t$, and that were exported in year $t$ but not in year 2000. Within the "new entrants" group, the "new exporters" margin refers to year $t$ firms that were not involved in exports in 2000, while the "adders" margin encompasses the export of new goods in year $t$ by firms which exported other goods in 2000 .

After we classified our firms based on their export activities, we calculated the market share changes associated with each margin between 2000 and 2006, to provide information for overall exports as well as firm groups classified by ownership. We start by calculating the market share tied to each margin $m$ (including the incumbents, exiters, new exporters, and adders) for each HS 6-digit product $h$ in each year $t, E_{X}$ share $_{m h t}=$ 
$E X_{m h t} /\left(\sum_{m h} E X_{m h t}\right)$. Next we take the difference in the market share between 2000 and 2006 for each product $h$, and calculate the average difference for each margin across products. $^{9}$

Panel A of Table 1 reports the changes in export market shares disaggregated by response margin and ownership. ${ }^{10}$ Column 1 provides the decomposition for China's overall exports, while columns 2 through 4 provide the decomposition for each type of ownership: state-owned enterprises (SOE), foreign-invested enterprises (FIE) and domestic private firms (DOM). It should be noted that for each margin, the sum of market share changes made by the different ownership groups sums to the market share change for overall exports at the same margin. In other words, for each row, the last three columns sum to the first column.

The dramatic aggregate reallocation of China's U.S. exports between new entrants and exiters is reflected by the market share data reported in Panel A of Table 1. Overall export growth was disproportionately driven by the changes along the extensive margin, with the largest reallocation occurring between exiting exporters (who experienced a 76 percentage point market share reduction) and the activities conducted by new exporter entrants (an increase in share of 67 percentage points). Among new entrants, the market share growth generated by the adders (a 19 percentage point increase) was considerably smaller than contributions associated with new exporters.

In Panel A, the shares of new entrants and exiters are calculated based on the total export values in 2006 and 2000 respectively. Since the total export value grew during this interval, it is also informative to trace the changes in the number of active firms by firm type. Thus to provide information on this margin, we follow Eaton, Eslava, Kugler and Tybout (2007) in tracing the change in the number of exporting firms to the contributions tied to new entrants and exiters. In particular, we measure the contribution of each margin $m$ to the growth in the number of exporting firms for each product $h$ as $\frac{\mathrm{dEXNum}_{m h}}{\left(N_{h 00}+N_{h 00}\right) / 2}$,

\footnotetext{
${ }^{9}$ The market share for each margin $m$ for each HS 6-digit product $h$ in each year $t, E_{\text {S }}$ share ${ }_{m h t}$, the difference in the market share between 2000 and 2006 for each product $h, D_{-} E X \operatorname{share}_{m h}$, and the average difference for each margin across products, $A V G_{-} D_{-} E X$ share $_{m}$, are defined respectively as: EXshare $_{m h t}=E X_{m h t} /\left(\sum_{m} E X_{m h t}\right), D_{-} E_{X}$ share $_{m h}=$ EXshare $_{m h 06}-$ EXshare $_{m h 00}$, and $A V G_{-} D_{-} E X$ share $_{m}=\left(\sum_{h} D_{-} E X\right.$ share $\left._{m h}\right) / H$, where $H$ is the total number of distinct HS 6-digit products. Note products, which are not exported in any of the two years, are dropped from the calculation.

${ }^{10}$ Differences in the table are marked with stars if they are statistically significant. Triple stars, *** , represent a significance level of $1 \%$. We obtain the statistics by running regressions of the changes in market shares on a constant. For comparison, we also examined the decomposition based on changes in market shares between 2000 and 2002. Since the results are very similar, they are reported in Appendix Table 1.
} 
where $\mathrm{N}_{\mathrm{ht}}$ is the total number of firms exporting product $h$ in year $t$ and $\mathrm{dEXNum}_{\mathrm{mh}}$ is the change in the number of exporting firms related to margin $m$ for product $h^{11}$ Next, we calculate the average contribution, based on the individual product-level measures. These measures are reported in the Panel B of Table A, column 1. The contribution of each margin can be further decomposed based on firm ownership types and are reported in columns 2 to 4 .

Compared to Panel A of Table 1, the contribution of the new exporter margin is magnified in Panel B. The total number of new exporters is about twice as large as the number of exiters. Within the new exporters, the number of domestic private firms exceeds the total number of exiting firms. Although the two panels of Table 1 provide different perspectives, they each convey the same key message: Chinese trade experienced a remarkable aggregate reallocation between new exporters and exiters, which largely entailed the replacement of SOE exiters by domestic private new firms. Since these are intriguing developments, our paper seeks to evaluate whether the reallocation was related to the reductions in trade policy uncertainty following China's WTO accession.

\subsection{Trade Policy Uncertainty Reduction}

As an outsider to the multiple rounds of tariff negotiations conducted through the GATT and successor WTO framework, China missed out on the formalized tariff reductions, which were conferred by the GATT/WTO process. Although the U.S. allowed China to benefit from the same tariff concessions that were offered to GATT/WTO members who received MFN treatment, China's MFN treatment was extended on a provisional basis that was subject to annual renewal.

Dumbaugh (2001) and Pregelj (2005) describe the politically controversial annual renewals of China's MFN tariff treatment prior to China's WTO accession. Since continued access to MFN treatment was not assured, any exporters had to consider the possibility of sharp tariff increases on their exports to the United States. Indeed, the possibility of trade action has not disappeared entirely following China's WTO accession, as there has been political pressure for U.S. trade action against China, to pressure China to increase the value its currency "in accordance with accepted market-based trading policies". ${ }^{12}$

\footnotetext{
${ }^{11}$ Note that the change of the number of exporting firms for the incumbent margin is zero.

${ }^{12}$ In contrast with the implied tariff penalty associated with loss of MFN, which would differ product by product, the proposed penalty for currency manipulation is often a single tariff (e.g., 25\%) which would be
} 
Nonetheless, China's WTO accession lowered the possibility for tariff adjustment via the loss of MFN treatment, and thereby, mitigated the worst-case tariffs, and the risk of change, that Chinese exporters needed to consider. The worst-case tariff before China's WTO accession, if China lost its MFN tariff treatment, was the United States' special rate of duty assigned to trade restricted countries. ${ }^{13}$ After China's WTO accession the worstcase tariff became the much lower schedule of WTO bound tariffs. ${ }^{14}$ As Figure 2 shows, the reductions in the worst-case tariff were substantial. The mean non-MFN tariff was roughly 32 percent while the mean bound tariff was only 3.6 percent. Moreover, the nonMFN tariff varied widely across product lines.

In contrast to the large reductions in trade policy uncertainty, the U.S. applied tariffs on imports changed almost imperceptibly in the early 2000's. As Table 2 shows, U.S. applied tariffs on imports averaged over the years 2000 and 2002 were roughly 3.65\%. Further, U.S. applied MFN tariffs declined by a mere 0.16 percentage points between 2000 to $2002 .^{15}$

Figure 3 provides more detail on the distribution of non-MFN tariffs by sector. Two patterns stand out. First, all U.S. sectors had worst-case tariffs that applied to non-MFN countries, and the worst-case tariff rates were very high. If the U.S. decided to revoke its MFN treatment of China's exports, no sector was immune from the threat of sizeable tariff increases. Second, within each sector, the non-MFN tariff varied dramatically across products. Since non-MFN tariffs were not uniform even within sectors, we can exploit the product-level tariff variation to identify exporters' responses to changes in trade policy uncertainty.

The worst-case tariffs were arguably exogenous. Pierce and Schott (2012) argue that, non-MFN tariffs were set decades ago and remained stable over recent decades. Similarly, since U.S. bound tariffs were also set well in advance of China's WTO entry, and were applied to all GATT/WTO members, they too should have been exogenous from Chinese considerations.

applied uniformly to all China's exports to the U.S., and which would be set to offset the degree to which China's currency were deemed to be underpriced.

${ }^{13}$ These tariffs are also interchangeably referred to as non-most favored nation treatment tariffs (nonMFN), non-normal trade relation tariffs (non-NTR) or Column 2 tariffs (Feenstra, Romalis \& Schott, 2002). They were originally set in the Smoot-Hawley Tariff Act of 1930.

${ }^{14}$ The United States permitted permanent MFN treatment to China in October 2000, but it is effective only once China joins the World Trade Organization. Negotiations on China's terms of membership in the WTO concluded in September 2001. Permanent MFN tariff treatment for China by the U.S. became effective on Jan 1, 2002. See http://www.wto.org/english/news \_e/pres01\e/pr243\_e.htm.

${ }^{15}$ There were no further large adjustments to applied tariffs through the period of 2002 to 2006. 


\section{Theory and Predictions}

In this section we develop a heterogeneous firm model to study the impact of trade policy uncertainty reduction on firms' export decisions. We find that uncertainty reductions induce new export entry, and more important, may also drive out incumbent firms when new entry increases competition in export markets.

\subsection{Basic Setting}

There are two countries, home and foreign. In addition, while there are two or more industries in the economy we set ideas by focusing on a single industry in which firms produce a continuum of differentiated goods. This industry is characterized by monopolistic competition, as in the Melitz (2003) framework.

Without loss of generality, we assume that the total expenditure on goods in this industry is a constant share of the economy's total income, as is the case when consumers have Cobb-Douglas preferences over industries. In our representative industry, we focus on the home firms' decisions regarding export to the foreign market. ${ }^{16}$ Thus all demand side variables in our model involve foreign country variables while all supply side variables in our model involve the home country.

Following Melitz (2003), there are an infinite number of time periods and the discount rate is $\rho$. In each period, the foreign country's preference for home products is given by CES preferences, or $U=\left[\int_{\omega \in \Omega} q(\omega)^{\frac{\sigma-1}{\sigma}} d \omega\right]^{\frac{\sigma}{\sigma-1}}$, where $\sigma>1$ is the elasticity of substitution between varieties. Consequently demand for each variety follows $q(\omega)=Q[p(\omega) / P]^{-\sigma}$ and the revenue each firm collects (tariff inclusive) is

$$
r(\omega)=R[p(\omega) / P]^{1-\sigma}
$$

where $P=\left[\int_{\omega \in \Omega} p(\omega)^{1-\sigma} d \omega\right]^{\frac{1}{1-\sigma}}, R=\int_{\omega \in \Omega} r(\omega) d \omega$ and $Q=U=R / P$.

\footnotetext{
${ }^{16}$ Since our empirical work focuses on firms' export outcomes, we only present our model's implications for firm exports. However, a simple extension of our model would enable us to study firm sales in the home market as well. For simplicity, we also ignore foreign firms producing in this industry. Implicitly, this assumes that Chinese firms have comparative advantage in their export goods, or that importers devote a fixed share of their expenditures to imports in each industry.
} 


\subsection{Trade Policy and Uncertainty}

We follow Feenstra and Romalis (2014), Caliendo, Feenstra, Romalis and Taylor (2015) and Handley and Limao (2014b) in assuming that exporting firms face an ad valorem tariff $v$ charged by the foreign country such that $\tau=1+v>1$. That is, for a given Free on Board price $p^{*}$ received by the firm, it must charge consumers in the destination foreign market a price $p=\tau p^{*}$. Alternatively, given tariff inclusive revenue $r=p q$, the earnings received by the firm are $r / \tau$, and the tariff collected by the foreign government is $r((\tau-1) / \tau)$.

We follow Handley and Limao (2014a) in assuming that policy uncertainty concerns the applied tariff rate. Absent the protection of WTO membership, the foreign country may at any time decide to change its tariffs. We model this uncertainty as an arrival rate, $\lambda$, which characterizes the risk that the foreign country will choose to replace its current tariff schedule with an alternative tariff schedule in each period. If the foreign country decides to adjust its tariffs, the new tariff will be drawn from a distribution $H(\tau)$ with support [1, $\bar{\tau}]$, where $\bar{\tau} \geq \tau$ is the highest possible tariff levied by the foreign country. In our setting, this is equivalent to the U.S. removing China's MFN treatment, and applying the higher non-MFN tariffs to Chinese imports instead.

\subsection{Firm Decision}

On the supply side, prior to production each firm must pay a one-time sunk entry cost, $f_{e}$, to learn its productivity, $\varphi$, which is drawn from a common distribution with c.d.f. $G(\varphi)$ and p.d.f. $g(\varphi)$. When firms make their entry decisions, they are aware of the current applied tariff rate and the degree of all future trade policy uncertainty.

Upon learning their productivities, firms decide next whether to produce (and export). If the firm decides to export to the foreign market, it pays a per-period fixed export cost, $M^{\eta} f$, where $M$ is the total mass of exporting firms, and $\eta \geq 0$ represents the degree of congestion externalities involved in entering export markets. In our setting the fixed export cost rises with the number of exporters due to increased competition from other exporting firms for the resources that are used in the provision of the export fixed costs. In the literature, this specification of fixed costs represents an imperfectly elastic supply of a specific factor which is required for entry. ${ }^{17}$ We note that the increase in export fixed costs in the face of intensified export activity is also consistent with our later

\footnotetext{
${ }^{17}$ See Bergin and Lin (2012), Berentsen and Waller (2010) and Rocheteau and Wright (2005) for examples motivated by search and advertising costs.
} 
empirical finding (see section 5) that new exporters charged lower prices while producing higher quality export goods as compared with exiting firms.

Given the timeline for firm decisions, the firm problem can be solved backward. First, conditional on given aggregate variables, the firm calculates its profits at varying tariff levels. Second, based on information on tariff levels and trade policy uncertainty, the firm calculates its present value of expected profits. Third, the firm compares export profits with the per-period fixed costs of export as it determines whether to export or not. Finally, potential entrants decide whether to pay the entry cost and to learn their productivity.

\subsubsection{Firm Production in Each Period}

Without loss of generality, we assume that foreign expenditure in each period, $R$, is given exogenously. We assume further that the home wage is fixed and normalized to unity.

Given tariffs charged by the foreign government, the variable profit the firm will earn is $v(\varphi) \equiv\left(\frac{p}{\tau}-\frac{1}{\varphi}\right) q$. Profit maximization given CES preferences over varieties leads to the firm's pricing rule,

$$
p(\varphi)=\frac{\sigma}{\sigma-1} \frac{\tau}{\varphi}
$$

Consequently, the firm's variable profit is given by $v(\varphi)=\left(\frac{\sigma}{\sigma-1}-1\right) \frac{q}{\varphi}=\frac{\sigma}{\sigma-1} \frac{\tau q}{\varphi} \frac{1}{\sigma \tau}=\frac{r(\varphi)}{\sigma \tau}$.

Substituting the pricing rule, Eq. (2), into the firm's revenue function, Eq. (1), and the variable profit equation, we get, respectively,

$$
r(\varphi)=R\left[\frac{\sigma-1}{\sigma} \frac{P \varphi}{\tau}\right]^{\sigma-1}
$$

and

$$
v(\varphi)=\frac{R}{\sigma}\left(\frac{\sigma-1}{\sigma} P \varphi\right)^{\sigma-1} \tau^{-\sigma}
$$


Since all firms with the same productivity will charge the same price, the aggregate price index can be rewritten as $P=\left[\int_{0}^{\infty} p(\varphi)^{1-\sigma} M \mu(\varphi) d \varphi\right]^{\frac{1}{1-\sigma}}$, where $\mu(\varphi)$ is the p.d.f. of the productivity distribution for surviving firms. Substituting the pricing rule, Eq. (2), into the aggregate price, it becomes $P=\frac{\sigma}{\sigma-1} \frac{\tau}{\tilde{\varphi}} M^{\frac{1}{1-\sigma}}=p(\tilde{\varphi}) M^{\frac{1}{1-\sigma}}$, where $\tilde{\varphi} \equiv\left[\int_{0}^{\infty} \varphi^{\sigma-1} \mu(\varphi) d \varphi\right]^{\frac{1}{\sigma-1}}$ is the average productivity of surviving firms.

When we substitute the aggregate price into Equations (3) and (4), each firm's revenue and variable profit become

$$
r(\varphi)=\frac{R}{M}\left(\frac{\varphi}{\tilde{\varphi}}\right)^{\sigma-1}
$$

and

$$
v(\varphi)=\frac{1}{\tau \sigma} \frac{R}{M}\left[\frac{\varphi}{\tilde{\varphi}}\right]^{\sigma-1}
$$

Similar to Melitz (2003), it is easy to derive the following conditions,

$$
R=\operatorname{Mr}(\tilde{\varphi}), V=M v(\tilde{\varphi}) \text {, and } Q=M^{\frac{\sigma}{\sigma-1}} q(\tilde{\varphi})
$$

where $V$ is the total variable profit obtained by all participating firms.

\subsubsection{Export Participation}

A firm's export participation decision is based on its present value of variable profit and the fixed cost of export. The present value of variable profits for a firm with productivity, $\varphi$, is

$$
v_{p}\left(\tau_{t}, \varphi\right)=v\left(\tau_{t}, \varphi\right)+\rho\left((1-\lambda) v_{p}\left(\tau_{t}, \varphi\right)+\lambda E_{\tau} v_{p}\left(\tau_{t+1}, \varphi\right)\right)
$$

where the expectation term is taken based on the distribution of possible tariffs. Taking expectations on both sides, we have $E_{\tau} v_{p}(\tau, \varphi)=\frac{1}{1-\rho} E_{\tau} v(\tau, \varphi)$. Substituting this back into Eq. (7), the present value of profits becomes, 


$$
v_{p}\left(\tau_{t}, \varphi\right)=\frac{1}{1-\rho}\left(\delta_{a} v\left(\tau_{t}, \varphi\right)+\delta_{E} E_{\tau} v(\tau, \varphi)\right)
$$

where $\delta_{a}=\frac{1-\rho}{1-\rho(1-\lambda)}, \delta_{E}=\frac{\rho \lambda}{1-\rho(1-\lambda)}$ and $\delta_{a}+\delta_{E}=1$.

We note that terms in the right-hand brackets of Eq. (8) represent a weighted average of current variable profit based on the current tariff, $\tau_{t}$, and the unconditional expected variable profit which accounts for the uncertainty regarding future tariff changes. If trade policy uncertainty rises, which is represented by an increase in the expected arrival rate, $\lambda$, the firm will increase the weight on the term for the expected variable profit, while decreasing the weight it places on its current profit that is based on currently applied tariffs.

Substituting the variable profit function, Eq. (6) into Eq. (8), we further simplify the present value of variable profit as

$$
v_{p}\left(\tau_{t}, \varphi\right)=B R T_{t} \varphi^{\sigma-1}
$$

where $B=\frac{1}{M \sigma(1-\rho) \tilde{\varphi}^{\sigma-1}}$ and $T_{t}=\delta_{a} \tau_{t}^{-1}+\delta_{E} E_{\tau}\left(\tau^{-1}\right)$.

To gain further intuition about the compound tariff term, $T$, note that this term depends on the current applied tariff, as well as an expected term related to the tariff distribution and weights. In addition, to gain intuition about the decisions facing Chinese firms at the beginning of the 2000's, prior to China's WTO entry, recall that the applied tariff is relatively low, close to the lower bound of the distribution $H(\tau)$, so that $\tau_{t}^{-1}$ is relatively high and $\tau_{t}^{-1}>E_{\tau}\left(\tau^{-1}\right)$.

The uncertainty facing exporting firms can now be summarized by two terms. The first term is the expectation term, $E_{\tau}\left(\tau^{-1}\right)$. If the unconditional tariff distribution is further away from the applied tariff, $\tau_{t}$, then this expectation term is smaller. For example, if the tariff distribution follows a uniform distribution, then the larger is the upper bound of the tariff distribution, the smaller is this expectation term. In practice, as discussed in section 2, considering that the worst case scenario tariffs faced by Chinese firms in the US are the non-normal trade relation tariffs (non-NTR tariff) before WTO accession and a much lower WTO bound tariff after WTO accession, there is then a shift 
for the tariff distribution toward the applied low tariffs and thus the expectation term increases. In our empirical application, since the reductions in the worst-case tariffs differ across products, the variation in the expectation term is our main source of identification.

The second factor which influences the level of trade policy uncertainty are the weights, $\delta_{a}$ and $\delta_{E}$, which in turn depend on the arrival rate, $\lambda$, for trade policy shocks. Since we assume $\tau_{t}^{-1}>E_{\tau}\left(\tau^{-1}\right)$, a larger arrival rate indicates a larger probability that tariffs will rise compared with the currently low applied rate. Thus, the compound tariff, $T$, is increasing in the arrival rate. In practice, China's WTO accession reduced the arrival rate characterizing the possibility of tariff increases since WTO membership guarantees MFN treatment. Thus WTO accession implies a decrease in the level of $T$. However, since the reduction in the arrival rate tied to MFN treatment is identical for all products, we cannot use this term to estimate the effects of uncertainty reduction on firm export decisions.

It is important to note that the term, $R T_{t}$, is the present value of expected revenue received by exporting firms. ${ }^{18}$ Thus, changes in the compound tariff term translate directly into changes in the revenue received by firms.

A firm starts to produce and export if the expected profit of exporting net of entry cost is greater than zero. I.e. for firms with expected profit of exporting, $\pi_{p}\left(\tau_{t}, \varphi\right)=$ $B R T_{t} \varphi^{\sigma-1}-M^{\eta} f /(1-\rho)$, the productivity cutoff, $\varphi^{*}$, can be determined as

$$
\pi_{p}\left(\tau_{t}, \varphi^{*}\right)=0 \text { or } \varphi^{* \sigma-1}=\left(M^{\eta} f\right) /\left((1-\rho) B R T_{t}\right) \quad(10) .{ }^{19}
$$

\subsubsection{Entry Decision and Equilibrium}

Given the cutoff productivity, the productivity distribution for surviving firms is given by,

$$
\mu(\varphi)=\left\{\begin{array}{ll}
\frac{g(\varphi)}{1-G\left(\varphi^{*}\right)} & \text { if } \varphi \geq \varphi^{*} \\
0 & \text { if } \varphi<\varphi^{*}
\end{array} .\right.
$$

Accordingly, the average productivity is given by

$$
\tilde{\varphi}=\left[\frac{1}{1-G\left(\varphi^{*}\right)} \int_{\varphi^{*}}^{\infty} \varphi^{\sigma-1} g(\varphi) d \varphi\right]^{\frac{1}{\sigma-1}}
$$

\footnotetext{
${ }^{18}$ To see this, note that $R / \tau$ is the revenue received by firms in each period (exclusive of tariffs).

${ }^{19}$ In our model, firms exit the market only when their profit is less than zero. Thus, firms' exit decisions are endogenous. This is different from Melitz (2003) where firms may also exit due to exogenous death shock.
} 
Let $\bar{\pi}_{p}=\pi_{p}\left(\tau_{t}, \tilde{\varphi}\right)$ denote the average export profit for surviving firms. Free entry requires the expected value of export activity based on potential productivity draws to equal to the entry cost,

$$
0 * G\left(\varphi^{*}\right)+\bar{\pi}_{p} *\left[1-G\left(\varphi^{*}\right)\right]=f_{e}
$$

The free entry condition (FE) can then be rewritten as

$$
\bar{\pi}_{p}=\frac{f_{e}}{1-G\left(\varphi^{*}\right)} .
$$

Note that $\bar{\pi}_{p}=v_{p}\left(\tau_{t}, \tilde{\varphi}\right)-M^{\eta} f /(1-\rho)$ and $\frac{v_{p}\left(\tau_{t}, \widetilde{\varphi}\right)}{v_{p}\left(\tau_{t}, \varphi^{*}\right)}=\left(\frac{\widetilde{\varphi}}{\varphi^{*}}\right)^{\sigma-1}$, a second relation between the average profit and cutoff productivity level, the zero cutoff profit condition (ZCP), can be derived as

$$
\bar{\pi}_{p}=M^{\eta} f k\left(\varphi^{*}\right) /(1-\rho),
$$

where $k(\varphi)=\left(\frac{\widetilde{\varphi}(\varphi)}{\varphi}\right)^{\sigma-1}-1$.

The free entry condition (FE) and the zero cutoff profit condition (ZCP) here are almost identical to the ones derived in Melitz (2003), except that the mass of exporting firms positively affects fixed export costs. Thus, given the mass of firms, $M$, there exists a unique solution for the average profit and the cutoff productivity. Since the solutions are functions of the mass of firms, $\bar{\pi}_{p}(M)$ and $\varphi^{*}(M)$, Appendix A1 shows that these functions are increasing in the mass of firms, $M$.

To solve the equilibrium mass of firms, we recall the present value of variable profit, Eq. (9). It implies that the variable profit for the average productivity firm is

$$
v_{p}\left(\tau_{t}, \tilde{\varphi}\right)=\frac{R T_{t}}{(1-\rho) M \sigma}
$$

Consequently, the average profit is given by the following condition, which we name as the "market clearing condition" (or MC),

$$
\bar{\pi}_{p}=v_{p}\left(\tau_{t}, \tilde{\varphi}\right)-\frac{M^{\eta} f}{1-\rho}=\frac{1}{1-\rho}\left(\frac{R T_{t}}{M \sigma}-M^{\eta} f\right)
$$


Eq. (14) defines another relation between the average profit $\bar{\pi}_{p}$ and the mass of firms, $M$. In this equation, the average profit is a decreasing function in the mass of firms.

Thus there exists a unique pair of firm mass, $M$, and average profit, $\bar{\pi}_{p}$ which solves Eq. (11), (12) and Eq. (14). The cutoff productivity, $\varphi^{*}$, is also jointly determined when the mass of firms, $M$, is determined.

\subsubsection{Entry and Exit Dynamics}

To understand the entry and exit dynamics for the economy, it is helpful to review the equilibrium conditions for firm decisions. As there is no limit on firm entry, the equilibrium will be achieved in each and every period, starting from a hypothetical "first" period, in which the equilibrium is established. In the initial period, a pool of identical entrants, denoted by $M_{e}$, pay the entry cost and learn their productivities. Among these entrants, a mass, $M$, learn that their productivity exceeds the equilibrium cutoff productivity, $\varphi^{*}$, and become surviving firms. The remaining firms exit.

In subsequent periods, assume that the current applied tariff rate and the degree of future trade policy uncertainty do not change. If new entrants were to pay the entry cost and draw their productivities, some of them would draw high productivities and the mass of surviving firms, $M$, would increase. However, this would reduce the average profit as in Eq. (14) and consequently reduce the expected payoff of entry in Eq. (11). Thus, in the absence to changes to the economic conditions which shape profit opportunities, entry in subsequent periods is not predicted. As a result, all entries occur in the first period and there is no further entry and exit in subsequent periods unless conditions change.

Changes in applied tariff rates or the trade policy uncertainty introduce the type of change which will influence the mass of active firms. For instance, when there are reductions in trade policy uncertainty, or more specifically, when the worst-case tariff, $\bar{\tau}$, declines, the expectation term $E_{\tau}\left(\tau^{-1}\right)$ rises and the compound tariff term, $T_{t}$, rises. ${ }^{20}$ As an increase in $T_{t}$ implies higher expected payoffs to entry, as in Eq. (14), it will induce more entries to the market. Further entries increase the mass of firms and congestion externality consequently results in an increase in the cutoff productivity, $\varphi^{*}$. Since surviving firms from earlier period, are required to pay the per period fixed cost if they continue to export, they need to decide whether to produce or not based on Eq. (10). Incumbent firms with productivities above the new cutoff productivity level will find it

\footnotetext{
${ }^{20}$ When the current applied tariff rate is low compared with the worst case tariff, decreases in the arrival rate, $\lambda$, or a reduction in the applied tariff have similar effects, since either change increases $T_{t}$.
} 
profitable to remain in the market and thus will continue their participation in export. In contrast, as congestion costs raise the fixed costs of continued export, some lower productivity incumbent firms will exit the market if they find that their productivities is below the new cutoff level.

In sum, our model thus predicts that reduced trade policy uncertainty will lead to an increase in the mass of firms exporting to the foreign market. ${ }^{21}$ Moreover, as the mass of exporting firms increases the fixed cost of exporting faced by each exporter, some of the lower-productivity incumbent exporting firms can no longer survive and have to exit the export market. Therefore when trade policy uncertainty declines, our model predicts that we will observe export entry by more productive firms (new entrants with productivity level above the increased new cutoff productivity) at the same time that some less productive incumbent firms exit from export (incumbent firms with productivity between the old and the new cutoff productivities). This market reallocation outcome is the key prediction we test when we turn to our data.

\section{Data and Empirical Results}

Our theory predicts that trade policy uncertainty reductions will lead to a larger mass of exporting firms. In turn, due to general equilibrium effects, the cutoff productivity for continued export will increase, driving some of the lower-productivity incumbent exporting firms out of the export market. Thus, in this section we empirically test whether trade policy uncertainty reductions due to China's WTO accession led to firm entries and exits that support the predictions of our model.

\subsection{Data}

Our empirical analysis uses China's transaction-level customs data, which track the universe of exports by Chinese firms between the years 2000 and 2006. The dataset provides detailed information including firm identifiers, product codes (8-digit codes which we aggregate to the internationally comparable 6-digit HS codes), destination country (we only make use of the exports to the United States and countries of the European Union), trade regime (ordinary trade or processing trade), transaction value and quantity. ${ }^{22}$

\footnotetext{
${ }^{21}$ Without uncertainty, Caliendo, Feenstra, Romalis and Taylor (2015) also shows how changes of ad valorem tariffs may lead to firm entry in a Melitz type model.

${ }^{22}$ We restrict our attention to China-US trade because the worst-case tariff before China's WTO accession is only readily available for the U.S. However, in the robustness section, we also use China's export to the EU countries to serve as a control group.
} 
We obtain the MFN applied tariff and bound tariff from the WTO Tariff Download Facility. ${ }^{23}$ The dataset reports the import tariffs of WTO members, disaggregated to the 6digit HS codes. ${ }^{24}$ The non-MFN tariffs of the U.S. are from Feenstra, Romalis and Schott (2002). Similar to the customs data, the tariff data sets have different versions of HS codes for different years due to the 2002 HS revision. We concord all observations with HS 2002 codes into HS 1996 codes based on the concordance provided by United Nation. $^{25}$

We measure the trade policy environment using three variables. These variables are average applied import tariffs ( $\tau_{h}$, or avt), the change in applied import tariffs ( $d \tau_{h}$, or dat), and the change in tariff uncertainty $\left(\operatorname{dgap}_{h}\right)$. Tariffs are measured at the HS 6-digit product level.

The first tariff variable, $\tau_{h}$, measures the average U.S. tariff rate which was applied to imports of product $h$ between 2000 and 2002. The variable, $d \tau_{h}$, is constructed by subtracting the applied tariff rate in 2002 (after China's WTO accession) from the tariff rate applied tariff in 2000 (prior to China's WTO accession). Positive values of this measure imply that Chinese exporters benefitted from a reduction in applied tariffs. Finally, if we define gap as the difference between the worst-case tariff and the applied tariff in a given year, the reduction in uncertainty, $d g a p_{h}$, is then defined as $d g a p_{h}=$ $\left(\right.$ gap $_{2000}$, before WTO accession $)$ - (gap ${ }_{2002}$, after WTO accession). Positive values of $\operatorname{dgap}_{h}$ indicate that trade policy uncertainty was reduced. ${ }^{26}$ Summary statistics in Table 2 provide information on tariff levels, tariff changes and the degree of uncertainty reduction that followed China’s WTO entry.

Before we turn to estimation, we check raw data correlations to check whether the changes in China's U.S.-destined exports were consistent with an explanation based on uncertainty reduction. To this end, we assign each product to one of the four uncertainty groups based on the degree of uncertainty reduction. Products that had no change in uncertainty were assigned to the group one (Duncert1). This group accounts for about

\footnotetext{
${ }^{23}$ See http://tariffdata.wto.org/ReportersAndProducts.aspx

${ }^{24}$ In the dataset, much information related to the MFN applied tariff is provided. For example, within each 6-digit HS code, number of subheadings, number of tariff lines, number of national tariff lines with ad valorem duty, average of all ad valorem duties, minimum and maximum of ad valorem duty, percentage of applied duty free national tariff lines, and number of national tariff lines with non-ad valorem duty are reported. Similar information is provided for the MFN bound tariffs. We take the average of all ad valorem applied duties within a 6-digit HS code as its applied tariff while the average of all ad valorem bound duties as its bound tariff.

${ }^{25} \mathrm{http}: / /$ unstats.un.org/unsd/trade/conversions/HS\%20Correlation\%20and\%20Conversion\%20tables.htm

${ }^{26}$ If we construct our tariff measures replacing 2002 with later years in the 2002-2006 interval the tariff measure changes only slightly, since U.S. tariffs were stable during this period.
} 
$15 \%$ of all HS 6-digit products. Remaining products, which experienced non-zero changes in trade policy uncertainty, were assigned to three groups, Duncert2 to Duncert4. Of the products in this group the $1 / 3^{\text {rd }}$ of the goods that had the smallest reductions in uncertainty were assigned to the group Duncert2. Similarly, $1 / 3^{\text {rd }}$ of the goods with medium reductions in tariff uncertainty were assigned to group Duncert3, and the last $1 / 3^{\text {rd }}$ with the largest reductions in tariff uncertainty were assigned to the group Duncert4. ${ }^{27}$

If uncertainty reduction influenced export decisions, we should observe that China's export growth was most pronounced for products which benefitted from the largest reductions in trade policy uncertainty. Consistent with this prediction, Figure 4 shows that the largest growth in trade value and in the number of exporting firms was in the group of firms (Duncert4), which benefited the strongest reductions in tariff uncertainty.

As we formed our dataset, we constructed two measures of fixed export costs. The first is constructed based on the China's manufacturing survey data, and is given as the fixed assets of exporting firms. ${ }^{28}$ In particular, it is the weighted average of total fixed assets per 1000 RMB sales across firms exporting the good, where each firms' share in the exports of the good are used as weights. While this measure does not directly measure fixed export costs, Castro, Li, Maskus and Xie's (2013) work on the fixed cost of exporting indicates that fixed costs of export are correlated with such firm characteristics.

For a second measure of fixed export costs, we construct the intermediary share of exports as a proxy. ${ }^{29}$ The intermediary share of exports, imshare, is calculated as the intermediary export value as a share of the total export value for each product in 2006. Our use of imshare is motivated by the work of Ahn, Khandelwal and Wei (2011) and Bernard, Grazzi and Tomasi (2012), which show that the intermediary share of trade is higher for markets that are more costly to enter. To avoid endogeneity while ensuring that the market conditions are similar to those of the U.S., we use China's exports to non-US G7 countries to construct our product-level measures of the intermediary share.

\footnotetext{
${ }^{27}$ Specifically, group one includes all products whose dgap $\mathrm{h}$ was zero. The values for $d g a p_{h}$ for products in Group 2 ranged from 2.2 to 29.5 percentage points, while the value for products in Group 3 spanned from 29.5 to 40.1 percentage points. The value exceeded 40.1 percentage points for products in Group 4.

${ }^{28}$ For details about this dataset, see Feng, Li and Swenson (2015).

${ }^{29}$ We define a firm as an intermediary firm if the firm data had at least one of the two following indicators: 1) if its Chinese name includes characters such as international trade, import, export, shopping mall, supermarket, commercial, etc, as in Ahn, Kandwall and Wei (2011), and/or 2) if the firm was observed in China's 2008 enterprise census and the census categorized the firm as a wholesaler or retailer.
} 


\subsection{Baseline Results: Impacts and Reallocation}

Our baseline regression estimates

$$
\operatorname{dlnEXNum}_{\mathrm{mh}}=\alpha+\beta_{1} \text { dgap }_{\mathrm{h}}+\beta_{2} \mathrm{~d} \tau_{\mathrm{h}}+\beta_{3} \tau_{\mathrm{h}}+\beta_{4} \mathrm{f}_{\mathrm{h}}+\alpha_{\mathrm{hs} 2}+\varepsilon_{\mathrm{h}}
$$

The dependent variable is the change in the log number of exporting firms in margin $m$ for product $h$. As our focus is the extensive margin adjustment, we primarily study the new entrant and exiter margins.

The exact definition of the dependent variable varies across margins. Since the new entrant margin is zero by definition in year 2000, the variable dlnEXNum mh $_{\text {is }}$ the log number of new entrants for product $h$ in year $t$ after WTO accession. In later regressions, our new entrant margin is further divided into new exporter and adder margins. The dependent variables for these margins are defined similarly. In contrast, the dependent variable for the exiter margin is the log number of firms, which are categorized as exiters by year $t$ following China's WTO accession, for product $h$ in year 2000.

Trade policy variables were constructed following the definitions introduced earlier in this section. Our main variable of interest is $\operatorname{dgap}_{h}$, which measures the trade policy uncertainty reduction for product $h$. Since our model predicts that reductions in trade policy uncertainty will lead to exports by new entrants, we expect $\beta_{1}>0$. In other words, since positive values of $d g a p_{h}$ indicate that firms faced reduced uncertainty following China's WTO accession, we expect the improved environment to increase export activity. Our next policy variable, $d \tau_{h}$, captures the magnitude of changes in applied tariffs. Since reductions in applied tariff reductions have the same effect as decreases in trade policy uncertainty, our model predicts $\beta_{2}>0$. Finally, we include the average tariff level, $\tau_{h}$, to control for the possibility that tariff levels may have affected the cutoff productivity and therefore had an effect on the number of new firms entering the market.

Our estimation equations include at least one of the two measures of fixed export costs: the average fixed asset to sales ratio for exporting firms, and/or the product-level intermediary share of exports. The reason for including fixed costs is that, as shown in Eq. (10), fixed export costs are related to the cutoff productivity level. In particular, industries with higher fixed costs have a higher cutoff productivity. If the lower end of the productivity distribution is more densely populated with smaller firms, then the number of new firms entering the market may be larger in low fixed cost industries than in high fixed cost industries when trade policy uncertainty declines. We expect a negative 
coefficient on this variable, i.e., $\beta_{4}<0$. Finally, to control for industry-level economic factors that affect the level of new exports, we include HS 2-digit fixed effects.

Table 3 provides the first set of results. Beginning with column 1 we regress the log number of new entrants in 2006 on our trade policy variables: uncertainty reduction (dgap), the applied tariff reduction (dat) and the average tariff (avt). All standard errors are clustered at HS 2-digit level in Table 3 and in all subsequent regressions. We find that uncertainty reduction had a positive and significant effect on the growth of the number of new entrants, while the average tariff and the applied tariff reductions did not have significant effects.

In column 2, we add our measure of export fixed costs, average fixed assets to sales ratio for exporters, to the regression. As expected, we find that the coefficient on the fixed cost measure is negative and highly significant. However, the inclusion of fixed cost measure does not affect the sign or the significance of the coefficient on our uncertainty reduction measure, although the magnitude is slightly smaller. In column 3 , we add the second fixed cost measure, the intermediary share of exports. Now both measures of export costs have the expected negative coefficients, while our estimated effect of uncertainty reductions continues to indicate that declines in trade policy uncertainty contributed to the growth of the number of new entrants.

In columns 4-6 of Table 3 we move to the full estimation equation that adds HS 2digit fixed effects to the specification. The inclusion of these fixed effects is warranted first, if there is any concern that the fixed asset and intermediary share variables are imperfect measures of the fixed costs of exporting. The inclusion of HS 2-digit fixed effects is also desirable if there are sector-specific unobserved factors or trends that affected the extent of new entries by sector. In addition, to check whether our estimated coefficient magnitudes are sensitive to our choice of time frame, we examine three time periods: 2000 to 2002, to 2004 and to 2006, respectively. As we move across time horizons, our dependent variable (though not our independent variables) is updated accordingly. ${ }^{30}$

Comparison of columns 3 and 6, both of which reflect the 2000 to 2006 time horizon, shows that the inclusion of HS 2-digit fixed effects causes the estimated coefficient on uncertainty reductions to decline in magnitude. However, both estimates remain highly significant. In addition, if we compare the coefficient magnitudes across

\footnotetext{
${ }^{30}$ Updating independent variables would not affect the results since the applied tariffs and the worst case tariffs did not change meaningfully in the period following China's WTO accession.
} 
different time horizons (through comparison of the coefficients in columns 4 through 6), we note that the estimated coefficient on uncertainty reduction grows as we move from the two-year window to the four or six year interval. Thus, it appears that the full response to trade policy uncertainty reduction took a number of years to complete.

Similar to columns 4-6 in Table 3, Table 4 reports results when the new entrant margin is further divided into new exporter (columns 1-3) and adder margins (columns 46). Applying our basic estimation equation to these two margins separately, the estimates uniformly show that the intensity of new entrant activity, whether due to the activities of new exporters or adders, was greatest for products that experienced larger reductions in trade uncertainty.

There is one noticeable difference between the new exporter margin and the adder margin, however. In particular, in later years (2004 and 2006), uncertainty reduction had a larger impact on the new exporter margin than it did on the adder margin. The growing response of new exporters is intuitive, as we expect the time involved in adding new export products by existing exporters might be shorter than the time involved in making a fresh entry to export.

In columns 7-9 of Table 4, we turn to the exiter margin. Similar to findings on the new entrant margin, our results also show that larger magnitude reductions in tariff uncertainty were positively correlated with the strength of export destruction through the disappearance of Chinese exporters who had formerly been active in the U.S. market in 2000. Moreover, the magnitude of export destruction grew, as we move from the twoyear estimation window to longer intervals.

One concern regarding our results is that they might be driven by some special fastexpanding industries. For example, Amiti and Freund (2010) notes that between 2000 and 2006 Chinese exports shifted substantially away from low-tech products towards hightech products. Alternatively, Khandelwal, Schott and Wei (2013) shows how removal of quotas on Chinese textile and clothing exports and related institutional changes in China caused China's textile and apparel exports to grow at a high pace. To check whether our results are mainly driven by these special industries, we run regressions for a subset of sectors excluding the high-tech machinery and instrument sector and previously quotarestricted textile and apparel sector. We find similar results to those in Table 4 for this subsample (see Appendix Table 3), and thus conclude that our results are not restricted to unusual features of these particular sectors. 
In sum, in support of our model predictions, we provide evidence that reductions in tariff policy uncertainty let to simultaneous export entry and export exit in the affected products, with the strongest changes observed in those product sectors which experienced the greatest reductions in tariff policy uncertainty.

\subsection{Robustness}

As we evaluate our baseline regression it is important to ask whether there were omitted factors that were correlated with uncertainty reduction, which might have also affected export entry and exit by firms. In our initial regressions, we include variables such as applied tariff level, changes in applied tariff, measures of fixed costs and even HS 2-digit fixed effects to control for other confounding factors. However, to address the relevance of omitted variable bias, we employ the technique of using a control group which was not subject to comparable uncertainty reduction during our sample period. Thus, we study and compare the outcomes of U.S.-bound exports with exports that were destined for the European Union. In contrast to the United States, the European Union granted permanent MFN status to China long before 2000 (in 1985). ${ }^{31}$ China's accession to the WTO, therefore, had little effect on either the applied tariff or the policy uncertainty facing Chinese exports to the EU.

We thus take Chinese exports to the EU countries and the US to form a sample which we estimate via the following specification: ${ }^{32}$

$$
\begin{gathered}
d \ln \text { EXNum }_{\text {mhct }}=\sum_{j=2001}^{2006} \beta_{j} 1\{j=t\} 1\{c=u s\} \text { dgap }_{h}+\sum_{j=2001}^{2006} \delta_{j} 1\{j=t\} 1\{c=u s\} \\
+\sum_{j=2001}^{2006} \gamma_{j} 1\{j=t\} 1\{c=u s\} X_{h}+\delta_{h t}+\varepsilon_{h c t}
\end{gathered}
$$

The definition of the dependent variable for each margin $m$ is similar to our previous regressions, though it is now separately derived for each destination country $c$. The triple interaction term between the uncertainty reduction, $d g a p_{h}$, the indicator for the US, $1\{c=u s\}$, and year dummies, $1\{j=t\}$, is our coefficient of interest. This coefficient indicates whether differences in the U.S. realizations of the dependent variables compared with those for the EU countries in year $t$ were correlated with our measures of U.S. tariff uncertainty reduction.

\footnotetext{
${ }^{31}$ http://europa.eu/legislation_summaries/external_relations/relations_with_third_countries/asia/r14206 en.htm

${ }^{32}$ The derivation of this estimation equation can be found in Appendix A2.
} 
To see the value of this estimation approach, suppose there is a variable that is correlated with uncertainty reduction and also affects the dependent variable. Through our use of a control group, we are now able to account for effects that might be driven by factors such as Chinese industrial policies, technological advances, or any other variables originating from China which affected trade outcomes, and might also be correlated with trade policy uncertainty reduction. As long as these omitted factors had a common effect on trade, regardless of destination, our strategy will provide unbiased estimates of $\beta_{j} s$.

Nonetheless, to provide further certainty, we include further triple interaction term, $1\{j=t\} 1\{c=u s\} X_{h}$, which explicitly controls for some observable factors. In this term, $X$ is an array of product specific characteristics. In our reported results, we include the applied tariff level, the change of the applied tariff and the measures of fixed costs in the vector $X$.

Finally, as we now have introduced cross-country variation, we can include much stronger fixed effects in the estimation equation. In contrast with Eq. (15), which included controls for HS 2-digit fixed effects, now we include HS 6-digit product*year fixed effects. HS 6-digit product* ${ }^{*}$ country fixed effects are also implicitly included, as shown in Appendix A2.

Before we turn to the estimation results, two important points should be noted. First, although there was no policy uncertainty reduction in the EU market, our identification is based on the assumption that the uncertainty reductions in the US market have no impact on the EU outcomes. This assumption might be violated if there were spillover across markets. I.e., multi-market firms' views of the benefits of serving the EU market might be influenced by developments in the U.S. market (for example due to capacity constraints).

Although this is a valid concern, if present, it will lead to a downward bias to our estimated coefficients. Thus, this additional factor, if present, will not invalidate our results. However, to alleviate concerns about cross-market spillovers, in our EU sample of firms, we drop all firms that also exported to the US market.

Second, we need to take care in selecting our control group countries, so any omitted variables would have the same impacts on the US as on the control group countries. First, we limit our definition of EU countries to countries that were EU members by the year $2000 .^{33}$ Next, to provide a more stringent control group, we create a second country group with includes the EU members with import structures that were the most similar to

\footnotetext{
${ }^{33}$ These countries are: Austria, Belgium, Denmark, Finland, France, Germany, Greece, Ireland, Italy, Luxembourg, Netherlands, Portugal, Spain, Sweden and United Kingdom.
} 
those of the US. Based on the import structure similarity index introduced in Appendix A3, the stringent EU control group includes the United Kingdom, France and Germany.

Table 5 shows the results when we use the full EU sample. Columns 1-4 report results for the new entrant margin while 5-8 report the results for the exiter margin. For parsimony, we only report the coefficients for the triple interaction term between uncertainty reduction, $d g a p_{h}$, the indicator for the US, $1\{c=u s\}$, and the year dummies, $1\{j=t\}$.

As shown in column 1, the coefficients are positive and highly significant for all years. These coefficients indicate that, for products which experienced larger uncertainty reduction in the US, the strength of firm export entry to the U.S. exceeded the strength of entry to the EU market. In other words, changes in U.S. trade policy uncertainty differentially affected China's exports to the U.S., compared with China's exports to the EU. Moreover, the coefficient grows over time, consistent with results reported in Table 3, which imply that the export effects stimulated by developments in trade policy uncertainty take time to be fully realized. These patterns are preserved when we include more control variables in the vector $X$, as shown in columns 2 to 4 . Similarly, when we turn to the exiter margin, columns 5-8, the positive and highly significant coefficients on the triple interaction terms further support the findings presented in Table 4.

Due to our concerns about the use of the full EU sample as a control group for the US, we also ran our robustness check on the more stringently selected control countries which encompass the United Kingdom, Germany and France. We now observe that the coefficients on the triple interaction terms are slightly smaller than those in Table 5. Nonetheless, our Table 6 coefficients, whether for the new entrant margin or for the exiter margin, remain positive and highly significant. Thus, we have further confidence that our primary coefficient results are not driven by omitted variable bias.

\section{Uncertainty Reductions and a more Competitive Market}

Our theory predicts that tariff policy uncertainty reductions will drive some exporting firms out of the market due to the effects of market congestion on the costs of export. Moreover, the theory is clear that the firms which are induced to leave the export market, will have lower productivity when compared with the new export market entrants. While section 4 has confirmed the presence of strong reallocation effects tied to product-level tariff uncertainty reduction, we now turn to this second prediction. In particular, we now seek to confirm whether the new export entrants were more productive than the exiting exporters and whether tariff uncertainty reduction intensified market competition. 
To address these questions, we now compare the price and the quality of HS 6-digit products sold by new exporters and exiting exporters in the US market. ${ }^{34}$ Further, we analyze whether there were any differences between the characteristics of goods sold by the two groups of firms, and whether the differences were related to uncertainty reduction.

Finally, although our comparison of the price and quality of exported goods shipped by new exporters and export exiters provides indirect evidence on the relative efficiency of these two types of firms, price and quality are not direct measures of firm productivity. Thus to provide direct evidence on this topic, we also compare the productivities of new exporters and export exiters in Appendix A5. ${ }^{35}$ There, consistent with the price and quality results presented in this section, we further document that new exporters were generally more productive than were exiting exporters.

\subsection{Product Prices}

We begin by testing whether the degree of uncertainty reduction had an influence on aggregate product prices. If the reallocations due to uncertainty reduction intensified competition, we expect smaller aggregate price increases in products that experienced larger declines in trade policy uncertainty.

In this exercise we first calculate the weighted average price for each HS 6-digit product $h$ in each year $t$ across all firms exporting the product, using each firm's export quantity share, $\theta_{\text {fht }}$, as weights, or $\overline{\mathrm{P}}_{\mathrm{ht}}=\sum_{\mathrm{f}} \theta_{\mathrm{fht}} \mathrm{p}_{\mathrm{fht}}$. In this expression firm export quantity shares are given by $\theta_{\mathrm{fht}}=\mathrm{q}_{\mathrm{fht}} / \sum_{\mathrm{f}} \mathrm{q}_{\mathrm{fht}}$, where the quantity of product $h$ exported by firm $f$ in year $t$ is $\mathrm{q}_{\mathrm{fht}}$. We then compute the percentage change in average product price for each product $h$ between year $t$ and year 2000, using the formula $\Delta \bar{P}_{h t}=\left(\bar{P}_{h t}-\bar{P}_{h 2000}\right) / \bar{P}_{h 2000}$. Following our variable construction we regress the

\footnotetext{
${ }^{34}$ We also provide a comparison on the transaction characteristics of exporting adder firms and export exiters in Appendix A4, which highlights similar reallocation effects on prices and qualities.

${ }^{35}$ Due to a number of practical considerations, TFP comparison involves a subset of the firms from our full sample of trade transactions. First, estimating TFP requires data that are collected through China's manufacturing census and thus we are only able to provide TFP measures for manufacturing firms. Second, before we estimate TFP for manufacturing firms, through firm-level information contained in the Chinese manufacturing census dataset, we must first match the firms with the custom's data, which use a different set of numerical identifiers. (For details of the manufacturing census dataset, TFP estimation and matching of datasets see Feenstra, Li and Yu (2014) and Feng, Li and Swenson (2012)). The third and most important problem with using TFP estimates for this project is that the TFP measures are firm-specific as is standard in the literature, rather than market or product specific. Since firms may export multiple products and a single firm may have different productivities for the products it produces, the use of a single productivity estimate, TFP, for all products produced by the same firm, masks important information of firm productivity at product level. Since we are unable to compare firm efficiency at product level using TFP, as we do using prices and qualities, we relegate our TFP results to the appendix.
} 
product price change measures on the product-level measures of uncertainty and applied tariff reductions. ${ }^{36}$

Table 7 displays the results for the regressions of product level price changes between 2000 to year $t(t=2002,2004$ and 2006) on the magnitude of trade policy uncertainty reductions. For reference, column 1 of Table 7 regresses our measures of product price changes on a constant only, to uncover the average change in unit export prices for all products. We find that average product prices increased by roughly $29 \%$ between 2000 and 2002. When we add the trade policy measures to the regression, our results in column 2 reveal a negative and significant coefficient on uncertainty reductions, which indicates that products that experienced larger tariff uncertainty reduction were characterized by smaller price increases. If we apply this regression framework to the longer time spans running to 2004 or 2006, the data reveal the same dampening effect of uncertainty reductions on export product prices.

The Table 7 observation that products that experienced larger tariff uncertainty reductions were characterized by smaller unit export price increases, could arise if market reallocation induced entry by more productive new exporters, who were capable of exporting products at lower prices than were the firms that decided to exit from export. To search for evidence of this mechanism, we compare the product-level prices charged by new exporters with the prices charged by exiting exporters.

Since new exporters and exiters are not simultaneously observed, the comparison involves a comparison of new exporter prices in a post-entry year $t(t=2002,2004$ and 2006) with the prices of exiters in year 2000, prior to their exit from export. ${ }^{37}$ We thus pool new exporters and exiters in a single sample and then run the following regression:

$$
\begin{gathered}
\operatorname{lnp}_{\text {foh }}=\alpha+\beta_{1} 1\{N \text { NewExp }\}_{f}+\beta_{2} 1\{N e w E x p\}_{f} d g a p_{h}+\beta_{3} 1\{N e w E x p\}_{f} d \tau_{h}+\delta_{h}+\delta_{o} \\
+\varepsilon_{f o h}
\end{gathered}
$$

where $\ln p_{f o h}$ is the log price of product $h$, sold by firm $f$ of ownership type $o$. As stated above, the dependent variable is the log price in year $t$ for new exporters, but the log price in 2000 for exiting firms. The dummy variable, $1\{N e w E x p\}_{f}$, is an indicator which denotes whether a firm is a new exporter. While this variable is likely to capture

\footnotetext{
${ }^{36}$ We drop products whose prices change measures were either below the first or above the ninety-ninth percentile.

${ }^{37}$ We do not observe contemporaneous activity since the new exporter is becoming active in the same year that the exiter is leaving, while the new exporter was absent in the earlier year when the now exiter was active.
} 
differences related to firms by age cohort, it also captures differences that arise due to the fact that our observation of firm prices for export exiters are necessarily observed at a point in time prior to our observed prices for new entrants. The interaction terms interact the new exporter indicator variables with the product-level policy variables capturing reductions in tariff uncertainty and the applied tariff. To account for inherent productspecific variation in prices we include HS 6-digit product fixed effects. In addition, to capture any systematic price variation that is due to the form of firm ownership, we also include fixed effects for the different forms of ownership.

Our new regressions, which are reported in Table 8, test whether new exporters' products had lower prices than the products previously exported by exiting exporters, and whether any differences were related to product-level reductions in uncertainty. The first set of results, included in columns 1 and 2, are based on comparison of new exporters who did not export in 2000 but appeared by 2002, with exiters who exported in 2000 but ceased export by 2002. The coefficient on the new exporter indicator variable in column 1 is negative and highly significant, which demonstrates that controlling for product fixed effects, new exporters' prices in 2002 were lower than the exiters' export prices in 2000.

This result is strong and surprising since we would generally expect to see some price inflation over the two-year interval. Indeed, as shown by column 1 of Table 7, average export prices rose between 2000 and 2002. Thus, the negative coefficient in column 1 of Table 8 suggests that, on average new exporter charged lower prices in 2002 than did the average exiters in 2000. Taken together, the relatively low prices offered by new exporters reflect an even larger price gap if one accounts for the inflation that took place over the two-year interval.

Column 2 of Table 8 augments the regression with policy interaction terms. Further, since firms of different ownership may charge different prices, we also add firm ownership fixed effects to the regression. The coefficient on the regressor that interacts the new exporter dummy with tariff uncertainty reduction is negative and highly significant. This suggests that new exporters charged lower prices than exiters, and that the price difference was particularly pronounced for products that experienced larger tariff uncertainty reduction.

To check the robustness of our results, we perform a second set of comparisons, which define new entry and exit using changes between 2000, and the later years 2004 and 2006. Since the comparisons extend across a larger number of years, it is not surprising that columns 3 and 5 now suggest that new exporter unit values, controlling for 
HS6 product effects, were higher on average than the export prices charged in 2000 by firms that exited from export. Since these prices were observed four to six years after 2000, they would have been affected by any underlying inflation in China's production costs. Nonetheless, the relative price premium for new exporters relative to exiters' 2000 prices (4.2\% in 2004 and 18\% in 2006) is small relative to the export price inflation that was revealed in Table 7 (48\% in 2004 and 72\% in 2006). More important, if we add interactions between the tariff policy uncertainty reduction and the new exporter dummy, our result show that products which experienced larger policy uncertainty reductions had lower relative prices charged by new entrants when compared with exiter prices than products that experienced smaller changes in policy uncertainty. Thus, our results suggest that, due to the role of policy uncertainty reduction in encouraging entry by new exporters who charged relatively lower prices, uncertainty reductions increased market competition.

\subsection{Quality}

Although we conjecture that the lower price of new entrants relative to exiters were driven by higher productivity, an alternative explanation could be that the lower price for new exporters arose since new exporters chose to produce and sell lower quality products. To investigate whether this alternative is consistent with the data, we adopt the approach used by Khandelwal, Schott and Wei (2013) to gain evidence regarding the relative quality of exports that were sold by new exporters compared with the quality provided by firms that exited from export.

Following Khandelwal, Schott and Wei (2013), we incorporate the quality levels in the utility function and use data on sales to estimate quality levels. For this exercise, we assume utility is given by the CES function: $U=\left(\int(\eta q)^{\frac{\sigma-1}{\sigma}} d \omega\right)^{\frac{\sigma}{\sigma-1}}$, where $\eta$ represents the quality of the variety. The demand function for each variety is then $q=\eta^{\sigma-1} p^{-\sigma} P^{\sigma-1} Y$, where $p$ is the variety's price, $P$ is the aggregate price level and $Y$ is the aggregate expenditure on the good. Taking logs of the demand equation, we obtain $\ln q=-\sigma \ln p+\ln \left(P^{\sigma-1} Y\right)+(\sigma-1) \ln \eta$. This provides us with the following regression specification,

$$
\ln q_{f h t}=-\sigma \ln p_{f h t}+\alpha_{h t}+\mu_{f h t}
$$

which applies to individual firm $f$ exports of HS 6-digit products, $h$. In this regression equation product-year fixed effects, $\alpha_{h t}$ capture the effects connected to aggregate price 
$(P)$, and aggregate expenditure $(Y)$ as well as other year-specific unobservable factors that affect product-level export costs or demand.

Following estimation of the demand equation, we could potentially back out the quality levels using the estimated residual $\eta_{f h t}=e^{\widehat{\mu}_{f h t} /(\sigma-1)}$. However, since we plan to compare quality differences across firms within the same HS 6-digit product and the estimation for quality is performed for each HS 6-digit product, we could simply use the estimated residual term as the measure of quality. That is, for a pooled sample of new exporters and exporting exiters, we regress the estimated residual term, which we call "quality", on the new exporter dummy and its interactions with our measure of tariff uncertainty reduction and/or the applied tariff reduction. The specification for this regression is identical to Eq. (17), but with the dependent variable replaced by our firmproduct quality measures derived from estimation of the demand equation.

Table 9 displays the quality regression results. Columns 1,3 and 5 show that the quality of products exported by new exporters exceeded the quality of exports shipped by exiters, regardless of the time horizon we use for comparison. In columns 2, 4 and 6 we do not find that the magnitude of the quality premium provided by new exporters was related to the magnitude of the trade policy uncertainty reduction. Nonetheless, since our evidence suggests that new exporters provided higher, not lower, quality exports, we do not believe the lower prices associated with new firm exports were attributable to a choice to provide new exports of inferior quality. Instead, our results suggest that new exporters were more productive, produced higher quality goods and charged lower prices than exiting exporters. In turn, this trend may explain Mandel's (2013) observation that U.S. exports from other countries responded to Chinese competition by reducing markups by a magnitude of $30 \%$, and increasing marginal costs by $50 \%$ (presumably in a move to provide distinctly higher quality products compared with China).

Combining the results in Table 8 and Table 9 with the fact that market share reallocations associated with the activities of new exporters and exiting exporters were the most important driver of changes in extensive margin market share reallocation, shown in Table 1, we find that trade policy reductions induced the reallocation of export market share from high-price low-quality exiting exporters to low-price high-quality new exporters. Moreover, products which experienced larger policy uncertainty reductions had lower relative prices charged by new entrants when compared with exiting exporter prices, than was the case for the relative price differences for products that experienced smaller changes in tariff policy uncertainty. Taken together, these features of China's 
export market reallocation suggest that reductions in tariff policy uncertainty intensified product market competition.

\section{Conclusion}

In this paper, we document two important features of Chinese exports to the United States in the early 2000's. First, at the fine product-level there was a dramatic reallocation of export activities across firms following China's WTO accession. In particular, within product-level export lines, substantial export market share expansions by new exporters coincided with similar magnitude export market share losses by exiting exporters. The second important development at this time was the sizeable reduction in U.S. trade policy uncertainty which was provided by China’s WTO entry in 2001.

We argue that this aggregate reallocations can be explained by the reduction in trade policy uncertainty. To analyze the connection, we develop a model of heterogeneous firms which incorporates trade policy uncertainty. Due to general equilibrium effects that operate through changes in the mass of exporting firms, our model generates simultaneous export entries and exits by firms within sectors when trade policy uncertainty is reduced - a reallocation effect on which current literature is typically silent.

Empirically, we exploit the rich firm-level Chinese Customs dataset to test how the uncertainty reductions associated with China's WTO entry contribute to exporter dynamics. We find very strong export entry and exit responses by firms, in response to reductions in trade policy uncertainty. More importantly, when we compare the price and quality of exported products for new exporters versus exiting exporters, we find strong evidence that the new exporters charged lower prices even though they exported higher quality goods than did exiting exporters. Further, the degree to which new exporter prices were lower than those of exiters was larger for products that experienced larger uncertainty reductions.

When considered as a whole, our results suggest that tariff policy uncertainty reductions contributed to the aggregate reallocation of Chinese exports. In particular, tariff uncertainty reduction led to churning at the fine product level, and encouraged the entry of high-productivity low-price new exporters at the expense of low-productivity high-price exiting exporters. Overall, since trade policy uncertainty reduction for Chinese exporters may have intensified the competitiveness of China's U.S. exports, through increased quality and reduced prices, this change in policy may help explain the potency of the effects of China's increased exports to the U.S. on the US manufacturing sector and labor market. 


\section{References}

Ahn, JaeBin, Amit K. Khandelwal and Shang-Jin Wei. (2011) "The Role of Intermediaries in Facilitating Trade.” Journal of International Economics, 84: 73-85.

Alfaro, Laura and Maggie X. Chen (2015) "Selection and Market Reallocation: Productivity Gains from Multinational Production," Harvard Business School Manuscript.

Alessandria, George, and Horag Choi. (2007). "Do Sunk Costs Of Exporting Matter for Net Export Dynamics?” Quarterly Journal of Economics, 122(1): 289-336

Amiti, Mary and Freund, Caroline. (2010) “The Anatomy of China's Trade Growth.” in Robert C. Feenstra and Shang-Jin Wei, eds. "China's Growing Role in World Trade," NBER Books.

Autor, David H., David Dorn and Gordon H. Hanson. (2013) "The China Syndrome: Local Labor Market Effects of Import Competition in the United States.” American Economic Review, 103(6): 2121- 68

Autor, David H., David Dorn, Gordon H. Hanson and Jae Song. (2014) "Trade Adjustment: Worker Level Evidence.” Quarterly Journal of Economics, forthcoming.

Berentsen, Aleksander and Christopher Waller. (2010) "Optimal Stabilization policy with endogenous firm entry.” Federal Reserve Bank of St. Louis working paper 2009-032.

Bergin, Paul. and Ching-Yi Lin. (2012). "The Dynamics Effects of Currency Union on Trade.” Journal of International Economics, 87(2): 191-204.

Bernard, Andrew, Marco Grazzi and Chiara Tomasi. (2012) "Intermediaries in International Trade: Direct versus Indirect Modes of Export.” NBER Working Paper, 17711.

Caliendo, Lorenzo, Robert Feenstra, John Romalis and Allan Taylor. (2015) "Tariff Reductions, Entry and Welfare: Theory and Evidence for the Last Two Decades.” NBER working paper, \#21768.

Castro, Luis, Ben Li, Keith E. Maskus and Yiqing Xie. (2013) "Fixed Export Costs and Firm-Level Export Behavior.” University of Colorado, Manuscript.

Conconi, P., A. Sapir and M. Zanardi. (2013) "The Internationalization Process of Firms: From Exports to FDI.”, Discussion Paper 9332 (London: CEPR).

Debaere, Peter and Shalah Mostashari. (2010) "Do Tariffs Matter for the Extensive Margin of International Trade? An Empirical Analysis.” Journal of International Economics, 81(2) 163-169. 
Dumbaugh, Kerry. (2001) "Voting on NTR for China Again in 2001, and Past Congressional Decisions.” CRS Report for Congress, Order Code RS20691 (Congressional Research Service: The Library of Congress)

Eaton, Jonathan, Marcela Eslava, Maurice Kugler and James Tybout. (2007) "Export

Dynamics in Colombia: Firm-Level Evidence.” NBER Working Paper, \#13531.

Feenstra, Robert C., Zhiyuan Li and Miaojie Yu. (2014) "Exports and Credit Constraints under Incomplete Information: Theory and Evidence from China." Review of Economics and Statisitcs, 96(4): 729-744

Feenstra, Robert C. and John Romalis. (2014) "International prices and endogenous quality.” Quarterly Journal of Economics, 129(2):477-527.

Feenstra, Robert C., John Romalis and Peter K. Schott. (2002) "U.S. Imports, Exports and Tariff Data, 1989-2001.” NBER Working Paper 9387.

Feng, Ling, Zhiyuan Li and Deborah L. Swenson. (2012) "The Connection between Imported Intermediate Inputs and Exports: Evidence from Chinese Firms.” NBER Working Papers 18260.

Finger, J. Michael, and M. E. Kreinin, (1979) "A measure of 'export similarity' and its possible uses.” Economic Journal, 89: 905-912.

Handley, Kyle. (2014) "Exporting under Trade Policy Uncertainty: Theory and Evidence.” Journal of International Economics, 94: 50-66

Handley, Kyle and Limao, Nuno (2014a) "Trade and Investment under Policy Uncertainty: Theory and Firm Evidence.” American Economic Journal: Policy, forthcoming.

Handley, Kyle and Limao, Nuno. (2014b) "Policy Uncertainty, Trade and Welfare: Theory and Evidence for China and the U.S.” NBER Working Paper 19376.

Khandelwal, Amit K., Peter Schott and Shang-Jin Wei. (2013) "Trade Liberalization and Embedding Institutional Reform.” American Economic Review, forthcoming.

Lewis, Vivien. (2009) "Business cycle evidence on firm entry." Macroeconomic Dynamics 13(5): 605-624.

Mandel, Benjamin R. (2013) “Chinese Exports and U.S. Import Prices.” Federal Reserve Bank of New York, Staff Report No. 591.

Mayer, Thierry, Melitz, Marc J, and Giancarlo Ottaviano. (2014) "Market Size, Competition, and the Product Mix of Exporters," American Economic Review, 104(2): 495-536. 
Melitz, Marc J. (2003) "The Impact of Trade on Intra-Industry Reallocations and Aggregate Industry Productivity.” Econometrica, vol. 71(6):1695-1725,

Melitz, Marc J., and Fabio Ghironi. (2005) "International Trade and Macroeconomic Dynamics with Heterogeneous Firms.” Quarterly Journal of Economics 120 (3), 865915.

Melitz, Marc J. and Giancarlo Ottaviano. (2008) "Market Size, Trade, and Productivity.” Review of Economic Studies, 75, 295-316.

Melitz, Marc J. and Stephen J. Redding. (2013) "New Trade Models, New Welfare Implications,” NBER Working Paper, 18,919.

Melitz, Marc J. and Saso Polanec. (2012) "Dynamic Olley-Pakes Productivity Decomposition with Entry and exit,” NBER Working Paper, No. 18,182.

Nguyen, D. X.. (2012) "Demand uncertainty: Exporting delays and exporting failures." Journal of International Economics, 86(2), 336-344.

Pierce, Justin R. and Peter K. Schott. (2012) “The Surprisingly Swift Decline of U.S. Manufacturing Employment.” NBER Working Paper 18655.

Pregelj, Vladimir. (2005) "Normal-Trade-Relations (Most-Favored-Nation) Policy of the United States.” CRS Report For Congress RL31558.

Rocheteau, Guillaume and Wright, Randall. (2005) "Money in Search Equilibrium, in Competitive Equilibrium, and in Competitive Search Equilibrium.” Econometrica 73(1): 175-202.

Ruhl, K., Willis, J., (2014) “New exporter dynamics.” mimeo. 
Figure 1: China's Exports to the United States, 1992-2008

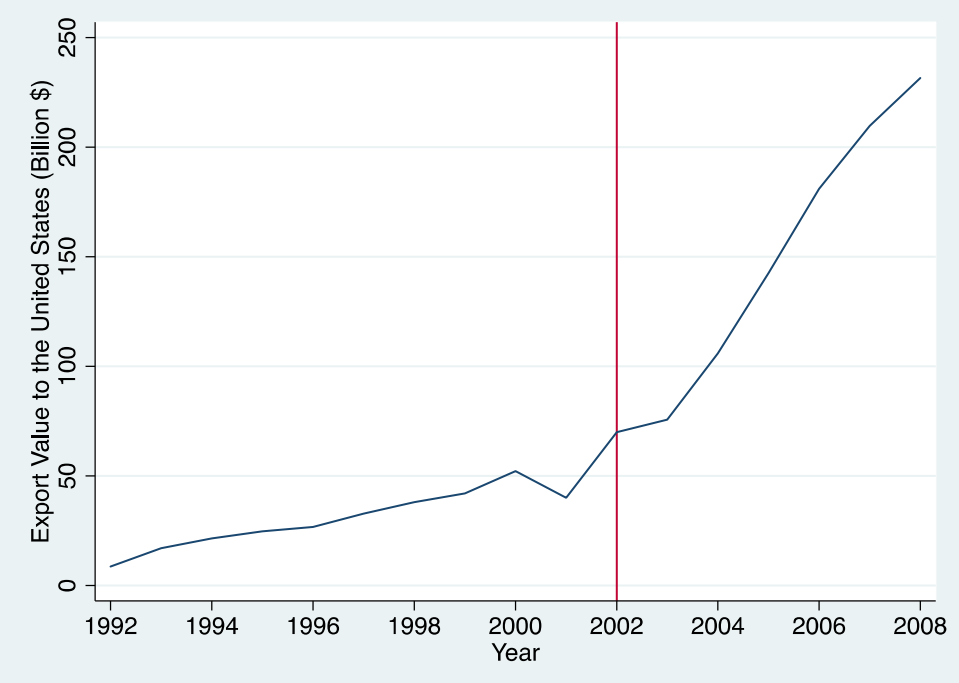

Data source: Chinese customs data obtained from UC Davis CID.

Figure 2: Distribution of Worst-case Tariffs across Tariff (Lines before and after China's WTO Accession)

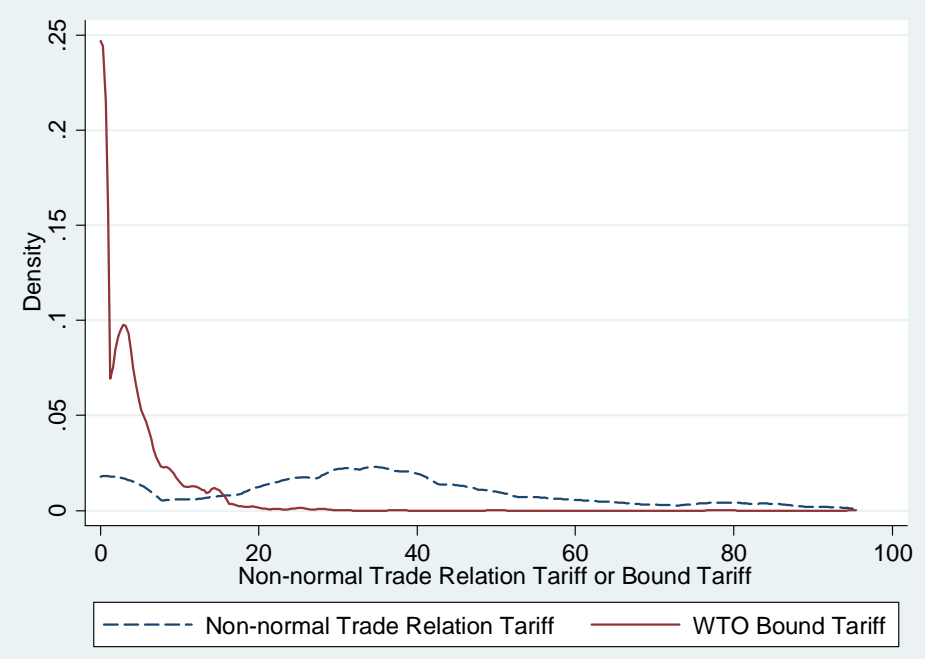

Note: This figure displays the kernel density of non-normal trade, or non-MFN tariffs (the worst-case tariff for China prior to its WTO accession) and the bound tariffs (the worst-case tariff following China's WTO accession) imposed by the United States across HS 6-digit tariff lines. 
Figure 3: Distribution of Worst-case U.S. Tariffs before China's WTO Accession, by Sector

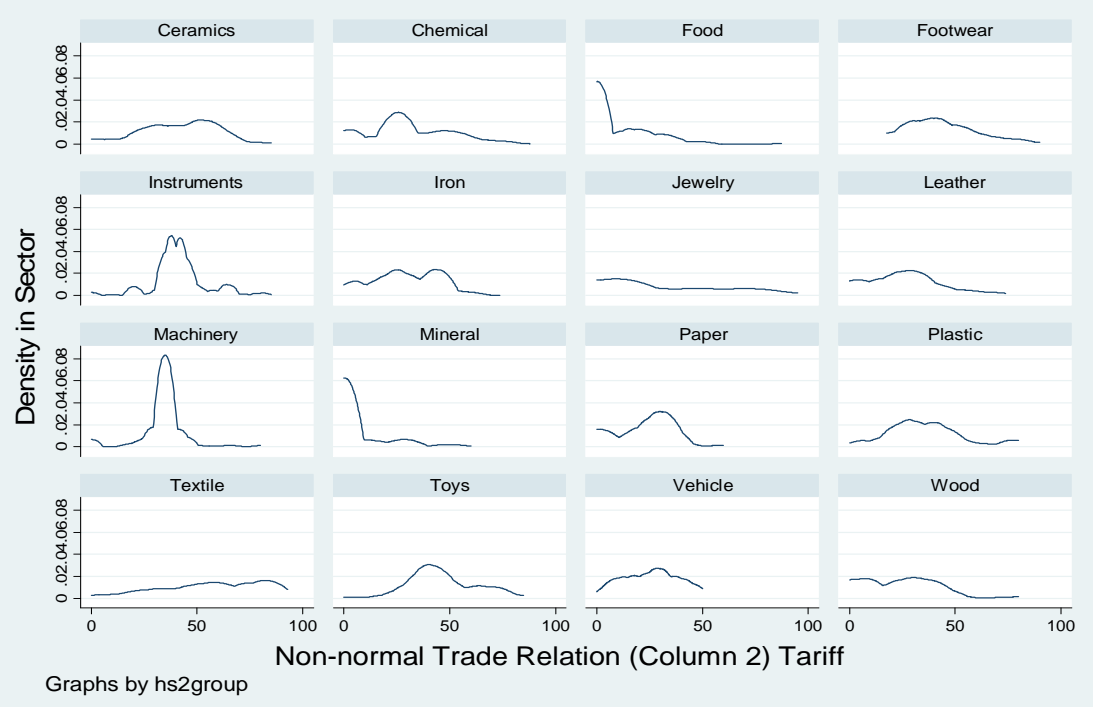

Note: Figures show the kernel density of non-normal trade relation tariffs across HS 6 digit product lines by sector. Sectors are defined according to HS classification (See Appendix Table 2). Some sectors, such as art products and ammunition, are dropped due to small export values.

\section{Figure 4: Tariff Uncertainty Reduction and Export Growth: Export Firm Numbers and Export Value}

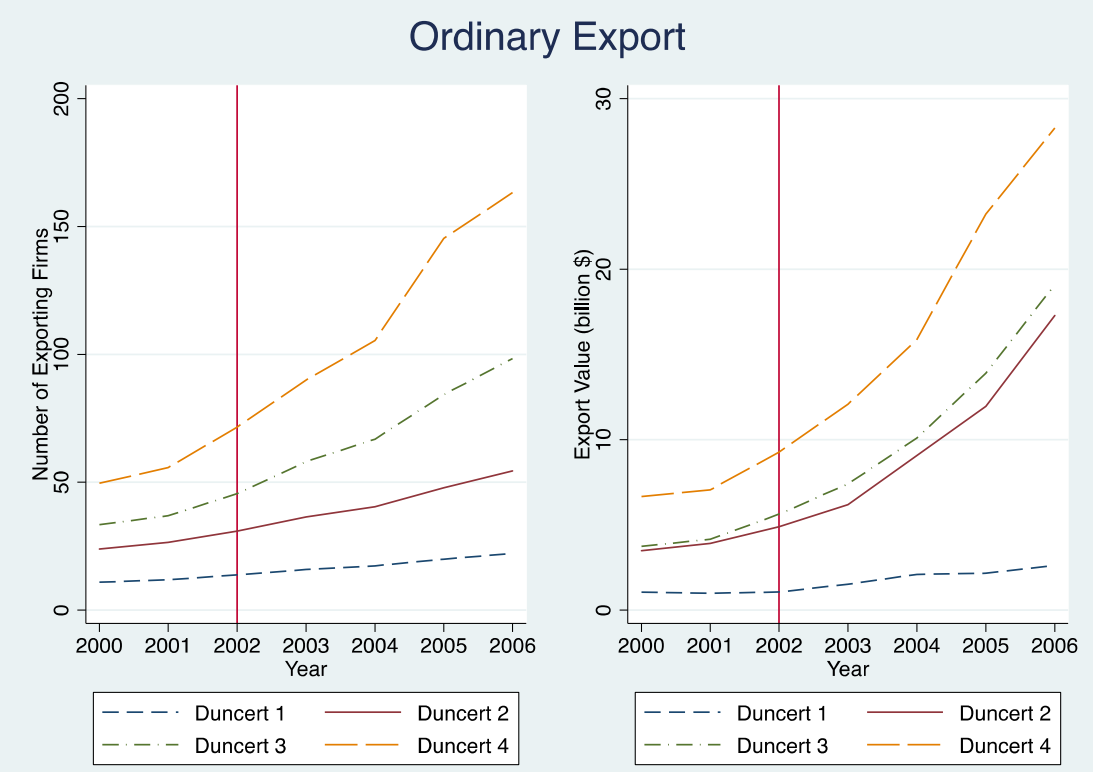

Notes: Each figure is based on China's ordinary exports to the U.S.. Products were assigned to the four groups, based on the degree of trade policy uncertainty reduction for China's U.S. exports following China's WTO accession. At the one end of the spectrum, products in Duncert1 experienced zero uncertainty reduction. In contrast, products in the group Duncert4 benefited from the largest reduction in U.S. trade policy uncertainty. The vertical axis of the left figure is the number of exporting firms averaged across HS 6-digit products within each group and the vertical axis for the right figure is the total export value for products in each group. Results for processing exports are similar. 
Table 1: Aggregate Reallocation of Export Activities

Panel A: Market Share Changes 2000-2006, Overall and by Firm Ownership

\begin{tabular}{lllll}
\hline Margin & $\begin{array}{l}\text { All } \\
(1)\end{array}$ & $\begin{array}{l}\text { SOE } \\
(2)\end{array}$ & $\begin{array}{l}\text { FIE } \\
(3)\end{array}$ & $\begin{array}{l}\text { Dom } \\
(4)\end{array}$ \\
\cline { 2 - 5 } $\begin{array}{l}\text { (1) Incumbents } \\
\text { Net entry }\end{array}$ & $-10.484^{* * *}$ & $-5.484^{* * *}$ & $-4.663^{* * *}$ & $-0.336^{* * *}$ \\
$\begin{array}{l}\text { (2) Exiters } \\
\text { (3) New Exporters }\end{array}$ & $-75.995^{* * *}$ & $-52.107^{* * * *}$ & $-19.761^{* * *}$ & $-4.127^{* * *}$ \\
(4) Adders & $67.144^{* * *}$ & $9.906^{* * *}$ & $26.836^{* * *}$ & $30.402^{* * *}$ \\
& $19.335^{* * *}$ & $11.468^{* * *}$ & $5.989^{* * *}$ & $1.879^{* * *}$ \\
(5) Total Net Entry & $10.484^{* * *}$ & $-30.734^{* * *}$ & $13.064^{* * *}$ & $28.154^{* * *}$ \\
(6) Total & 0 & $-36.218^{* * *}$ & $8.401^{* * *}$ & $27.817^{* * *}$ \\
\hline
\end{tabular}

Note: This table reports the average market share changes for different margins for the period 2000 to 2006. The data are averaged across HS 6-digit products, according to the margins of adjustment and the form of firm ownership. In each column, the contributions due to exiters, new exporters, and adders (displayed in rows 2 to 4 ) sum up to the values reported in row 5 (total net entry). Similarly, the market share changes due to incumbents (row 1) can be summed with the market share changes caused by total net entry (row 5) to compute the value displayed in row 6. Since the data are also disaggregated to show changes by ownership (SOE, FIE and Domestic), the values in the associated rows for columns 2 to 4 , can be summed to arrive at the overall change by margin, displayed in column 1 . Results are generated by regressing the changes in market shares for HS 6-digit products on a constant. Triple-stared values represent statistical significance at $1 \%$ level.

Panel B: The Growth of Firm Numbers 2000-2006, Decomposition by Margin and by Firm Ownership

\begin{tabular}{lllll}
\hline Margin & All & SOE & FIE & $\begin{array}{l}\text { Dom } \\
(1)\end{array}$ \\
\cline { 2 - 5 } & $(1)$ & $(2)$ & $(3)$ & 0 \\
(1) Incumbents & 0 & 0 & $-11.515^{* * *}$ & $-2.863^{* * *}$ \\
(2) Exiters & $-54.387^{* * *}$ & $-40.009^{* * *}$ & $26.340^{* * *}$ & $62.730^{* * *}$ \\
(3) New Exporters & $105.094^{* * *}$ & $16.024^{* * *}$ & $2.471^{* * *}$ & $2.809^{* * *}$ \\
(4) Adders & $29.891^{* * *}$ & $20.611^{* * *}$ & & \\
& & & & \\
(5) Net Growth Rate & $80.597^{* * *}$ & $-3.374^{* * *}$ & $21.295^{* * *}$ & $62.676^{* * *}$ \\
\hline
\end{tabular}

Note: This table reports the contributions to the exporting firm number growth for different margins and different firm ownerships for the period 2000 to 2006. The data are averaged across HS 6-digit products, according to the margins of adjustment and the form of firm ownership. In each column, the contributions due to exiters, new exporters, and adders (displayed in rows 2 to 4 ) sum up to the values reported in row 5 (net growth rate). Since the data are also disaggregated to show contributions by ownership (SOE, FIE and Domestic), the values in the associated rows for columns 2 to 4 , can be summed to arrive at the overall contribution by margin, displayed in column 1 . By definition the contributions due to incumbents (row 1) are zero. Results are generated by regressing the contributions to exporting firm number growth rate for HS 6 -digit products on a constant. Triple-stared values represent statistical significance at $1 \%$ level. 
TABLE 2: Tariff Measure Summary Statistics

\begin{tabular}{lcrrrr}
\hline $\begin{array}{l}\text { Variable } \\
\text { Tariff Policy Uncertainty Reduction }\end{array}$ & Obs. \# & Mean & Std. Dev. & Min & Max \\
$\begin{array}{l}\text { dgap (percentage points) } \\
\text { Change in Average Tariff Rate }\end{array}$ & 4721 & 29.99 & 20.37 & -56.56 & 145.5 \\
$\begin{array}{c}\text { dat (percentage points) } \\
\begin{array}{c}\text { Average Tariff Rate } \\
\quad \text { avt (percentage points) }\end{array}\end{array}$ & 4721 & 0.16 & 7.10 & -262.5 & 35 \\
\hline
\end{tabular}

Notes: Tariffs are measured at the HS 6-digit product level. The variable "avt" measures U.S. tariff rates averaged over the years 2000 and 2002. The definition for the variable measuring changes in applied tariffs, or "dat", is dat = the year 2000 (before WTO accession) applied tariff - the year 2002 (after WTO accession) applied tariff. Positive values reflect the reductions in applied tariffs. We define "gap" as the difference between the worst-case tariff and the applied tariff. The reduction in uncertainty "dgap" is then defined as dgap=(gap_2000, before WTO accession)-(gap_2002, after WTO accession). Positive values of the variable dgap imply that tariff uncertainty fell after China's WTO accession. 
Table 3: Trade Policy and Number of New Entrants by Product: Main Specification

\begin{tabular}{|c|c|c|c|c|c|c|}
\hline \multirow[t]{3}{*}{ Dependent } & \multicolumn{6}{|c|}{ Log number of new entrants in year $\mathrm{t}$ (new exporters and adders in year $\mathrm{t}$ ) } \\
\hline & \multicolumn{3}{|c|}{$\mathrm{T}=2006$} & \multirow{2}{*}{$\begin{array}{c}\mathrm{T}=2002 \\
(4)\end{array}$} & \multirow{2}{*}{$\begin{array}{c}\mathrm{T}=2004 \\
(5)\end{array}$} & \multirow{2}{*}{$\begin{array}{c}\mathrm{T}=2006 \\
(6)\end{array}$} \\
\hline & $(1)$ & (2) & (3) & & & \\
\hline \multirow[t]{2}{*}{ dgap } & $0.041 * * *$ & $0.034 * * *$ & $0.030 * * *$ & $0.016 * * *$ & $0.019 * * *$ & $0.018 * * *$ \\
\hline & $(0.004)$ & $(0.003)$ & $(0.004)$ & $(0.003)$ & $(0.003)$ & $(0.003)$ \\
\hline \multirow[t]{2}{*}{ dat } & -0.003 & -0.024 & -0.021 & 0.012 & 0.014 & $0.029 * *$ \\
\hline & $(0.022)$ & $(0.034)$ & $(0.034)$ & $(0.017)$ & $(0.015)$ & $(0.014)$ \\
\hline \multirow[t]{2}{*}{ avt } & -0.006 & -0.001 & 0.004 & 0.004 & 0.002 & $0.022 *$ \\
\hline & $(0.027)$ & $(0.026)$ & $(0.025)$ & $(0.011)$ & $(0.011)$ & $(0.011)$ \\
\hline \multirow[t]{2}{*}{ fixed_ass } & & $-1.542 * * *$ & $-1.523 * * *$ & $-0.815^{* * *}$ & $-0.952 * * *$ & $-0.906 * * *$ \\
\hline & & (0.213) & $(0.206)$ & $(0.153)$ & (0.167) & $(0.173)$ \\
\hline \multirow[t]{2}{*}{ imshare } & & & $-0.810 * * *$ & $-0.273 * *$ & $-0.405 * * *$ & $-0.504 * * *$ \\
\hline & & & $(0.160)$ & $(0.120)$ & $(0.141)$ & $(0.156)$ \\
\hline \multirow[t]{2}{*}{ Constant } & $1.327 * * *$ & $2.358 * * *$ & $2.958 * * *$ & $2.205^{* * *}$ & $2.610 * * *$ & $2.961 * * *$ \\
\hline & $(0.152)$ & $(0.196)$ & $(0.214)$ & $(0.131)$ & $(0.140)$ & $(0.160)$ \\
\hline$H S 2 d F E$ & No & No & No & Yes & Yes & Yes \\
\hline$N$ & 4685 & 3807 & 3572 & 3572 & 3572 & 3572 \\
\hline$R^{2}$ & 0.156 & 0.152 & 0.145 & 0.349 & 0.358 & 0.362 \\
\hline $\operatorname{adj} . R^{2}$ & 0.155 & 0.151 & 0.144 & 0.330 & 0.340 & 0.344 \\
\hline Log lik. & -9677.971 & -7665.135 & -7071.975 & -6105.080 & -6367.491 & -6548.150 \\
\hline $\mathrm{F}$ & 36.822 & 40.836 & 36.130 & 13.709 & 15.210 & 15.052 \\
\hline
\end{tabular}

Notes: Standard errors in () are clustered at HS 2digit level. The change in tariff uncertainty is labelled with (dgap), while the average applied import tariff is given by (avt), and the change in the applied tariffs is given by (dat). Industry fixed_assets relative to sales is measured by (fixed_ass), while the intermediary share of trade at the 6-digit level is given by (imshare). Statistical significance denoted by: ${ }^{*} \mathrm{p}<0.10,{ }^{* *} \mathrm{p}<0.05,{ }^{* * *} \mathrm{p}<0.01$. 
TABLE 4: Trade Policy and Number of Firms: New Exporters, Adders and Exiters

\begin{tabular}{|c|c|c|c|c|c|c|c|c|c|}
\hline \multirow[t]{2}{*}{ Dependent } & \multicolumn{3}{|c|}{$\begin{array}{c}\text { Log firm number (year t) } \\
\text { new exporters }\end{array}$} & \multicolumn{3}{|c|}{$\begin{array}{l}\text { Log firm number (year t) } \\
\text { adders }\end{array}$} & \multicolumn{3}{|c|}{$\begin{array}{c}\text { Log firm number at year } 2000 \\
\text { exiters (exit by year t) }\end{array}$} \\
\hline & $\begin{array}{l}t=2002 \\
(1)\end{array}$ & $\begin{array}{c}t=2004 \\
(2)\end{array}$ & $\begin{array}{c}t=2006 \\
(3)\end{array}$ & $\begin{array}{c}\mathrm{t}=2002 \\
(4)\end{array}$ & $\begin{array}{c}\mathrm{t}=2004 \\
(5)\end{array}$ & $\begin{array}{c}\mathrm{t}=2006 \\
(6)\end{array}$ & $\begin{array}{c}\mathrm{t}=2002 \\
(7)\end{array}$ & $\begin{array}{c}\mathrm{t}=2004 \\
(8)\end{array}$ & $\begin{array}{c}t=2006 \\
(9)\end{array}$ \\
\hline dgap & $\begin{array}{l}0.014^{* * *} \\
(0.003)\end{array}$ & $\begin{array}{l}0.018^{* * *} \\
(0.003)\end{array}$ & $\begin{array}{l}0.018^{* * *} \\
(0.003)\end{array}$ & $\begin{array}{l}0.014^{* * *} \\
(0.003)\end{array}$ & $\begin{array}{l}0.015^{* * *} \\
(0.003)\end{array}$ & $\begin{array}{l}0.014^{* * *} \\
(0.003)\end{array}$ & $\begin{array}{l}0.013^{* * *} \\
(0.003)\end{array}$ & $\begin{array}{l}0.014^{* * *} \\
(0.003)\end{array}$ & $\begin{array}{l}0.015^{* * *} \\
(0.003)\end{array}$ \\
\hline dat & $\begin{array}{c}0.005 \\
(0.017)\end{array}$ & $\begin{array}{c}0.010 \\
(0.018)\end{array}$ & $\begin{array}{l}0.026^{*} \\
(0.015)\end{array}$ & $\begin{array}{c}0.013 \\
(0.016)\end{array}$ & $\begin{array}{c}0.014 \\
(0.014)\end{array}$ & $\begin{array}{l}0.026^{* *} \\
(0.012)\end{array}$ & $\begin{array}{c}0.009 \\
(0.017)\end{array}$ & $\begin{array}{c}0.008 \\
(0.019)\end{array}$ & $\begin{array}{c}0.008 \\
(0.018)\end{array}$ \\
\hline avt & $\begin{array}{l}-0.000 \\
(0.011)\end{array}$ & $\begin{array}{c}-0.001 \\
(0.012)\end{array}$ & $\begin{array}{c}0.017 \\
(0.011)\end{array}$ & $\begin{array}{c}0.001 \\
(0.010)\end{array}$ & $\begin{array}{c}0.003 \\
(0.010)\end{array}$ & $\begin{array}{c}0.016^{*} \\
(0.009)\end{array}$ & $\begin{array}{c}0.005 \\
(0.012)\end{array}$ & $\begin{array}{c}0.007 \\
(0.013)\end{array}$ & $\begin{array}{c}0.006 \\
(0.012)\end{array}$ \\
\hline fixed_ass & $\begin{array}{c}-0.818^{* * *} \\
(0.155)\end{array}$ & $\begin{array}{c}-0.872^{* * *} \\
(0.160)\end{array}$ & $\begin{array}{c}-0.944^{* * *} \\
(0.170)\end{array}$ & $\begin{array}{c}-0.811^{* * * *} \\
(0.143)\end{array}$ & $\begin{array}{c}-0.771^{\text {**** }} \\
(0.128)\end{array}$ & $\begin{array}{c}-0.800^{* * *} \\
(0.154)\end{array}$ & $\begin{array}{c}-0.755^{* * *} \\
(0.148)\end{array}$ & $\begin{array}{c}-0.658^{* * *} \\
(0.148)\end{array}$ & $\begin{array}{r}-0.810^{* * *} \\
(0.156)\end{array}$ \\
\hline imshare & $\begin{array}{c}-0.190 \\
(0.128)\end{array}$ & $\begin{array}{c}-0.181 \\
(0.161)\end{array}$ & $\begin{array}{c}-0.391^{* *} \\
(0.152)\end{array}$ & $\begin{array}{c}-0.113 \\
(0.115)\end{array}$ & $\begin{array}{c}-0.064 \\
(0.143)\end{array}$ & $\begin{array}{l}-0.160 \\
(0.110)\end{array}$ & $\begin{array}{l}-0.026 \\
(0.137)\end{array}$ & $\begin{array}{c}0.095 \\
(0.155)\end{array}$ & $\begin{array}{c}0.018 \\
(0.126)\end{array}$ \\
\hline Constant & $\begin{array}{l}1.535^{* * *} \\
(0.134)\end{array}$ & $\begin{array}{l}2.137^{* * *} \\
(0.136)\end{array}$ & $\begin{array}{l}2.679^{* * *} \\
(0.152)\end{array}$ & $\begin{array}{l}1.796^{* * *} \\
(0.127)\end{array}$ & $\begin{array}{l}1.635^{* * *} \\
(0.124)\end{array}$ & $\begin{array}{l}1.549^{* * *} \\
(0.128)\end{array}$ & $\begin{array}{l}1.868^{* * *} \\
(0.125)\end{array}$ & $\begin{array}{l}1.809^{* * *} \\
(0.128)\end{array}$ & $\begin{array}{l}1.849^{* * *} \\
(0.127)\end{array}$ \\
\hline$H S 2 d F E$ & Yes & Yes & Yes & Yes & Yes & Yes & Yes & Yes & Yes \\
\hline$N$ & 3254 & 3350 & 3474 & 3254 & 3350 & 3474 & 3254 & 3350 & 3474 \\
\hline$R^{2}$ & 0.301 & 0.322 & 0.342 & 0.327 & 0.336 & 0.354 & 0.309 & 0.308 & 0.321 \\
\hline $\operatorname{adj} . R^{2}$ & 0.279 & 0.302 & 0.323 & 0.306 & 0.316 & 0.335 & 0.287 & 0.287 & 0.301 \\
\hline Log lik. & -5383.72 & -5941.62 & -6381.91 & -5349.44 & -5516.71 & -5641.60 & -5423.14 & -5703.70 & -5966.79 \\
\hline $\mathrm{F}$ & 12.716 & 13.781 & 15.261 & 14.061 & 13.071 & 16.026 & 9.986 & 8.425 & 11.046 \\
\hline
\end{tabular}


TABLE 5: Trade Policy Uncertainty and the Number of Firms, Difference in Differences Estimates: US comparison with the EU as the Control Group

\begin{tabular}{|c|c|c|c|c|c|c|c|c|}
\hline \multirow[t]{2}{*}{ Dependent } & \multicolumn{4}{|c|}{$\begin{array}{c}\text { Log firm number (year t) } \\
\text { new entrants (new exporter and adders) }\end{array}$} & \multicolumn{4}{|c|}{$\begin{array}{c}\text { Log firm number at year } 2000 \text { exited by year t } \\
\text { exiters }\end{array}$} \\
\hline & $(1)$ & $(2)$ & $(3)$ & (4) & (5) & (6) & (7) & (8) \\
\hline US*dgap*2001 & $\begin{array}{c}0.012^{* * *} \\
(0.001)\end{array}$ & $\begin{array}{c}0.014 * * * \\
(0.001)\end{array}$ & $\begin{array}{c}0.013^{* * *} \\
(0.001)\end{array}$ & $\begin{array}{c}0.012^{* * *} \\
(0.001)\end{array}$ & $\begin{array}{c}0.012^{* * *} \\
(0.001)\end{array}$ & $\begin{array}{c}0.014 * * * \\
(0.001)\end{array}$ & $\begin{array}{c}0.012^{* * *} \\
(0.001)\end{array}$ & $\begin{array}{c}0.012^{* * *} \\
(0.001)\end{array}$ \\
\hline US*dgap*2002 & $\begin{array}{c}0.015^{* * *} \\
(0.001)\end{array}$ & $\begin{array}{c}0.017 * * * \\
(0.001)\end{array}$ & $\begin{array}{c}0.015^{* * *} \\
(0.001)\end{array}$ & $\begin{array}{c}0.015^{* * *} \\
(0.001)\end{array}$ & $\begin{array}{c}0.012^{* * *} \\
(0.001)\end{array}$ & $\begin{array}{c}0.014 * * * \\
(0.001)\end{array}$ & $\begin{array}{c}0.012^{* * *} \\
(0.001)\end{array}$ & $\begin{array}{c}0.012^{* * *} \\
(0.001)\end{array}$ \\
\hline US*dgap*2003 & $\begin{array}{c}0.016 * * * \\
(0.001)\end{array}$ & $\begin{array}{c}0.018 * * * \\
(0.001)\end{array}$ & $\begin{array}{c}0.016^{* * *} \\
(0.001)\end{array}$ & $\begin{array}{c}0.016^{* * *} \\
(0.001)\end{array}$ & $\begin{array}{c}0.011^{* * *} \\
(0.001)\end{array}$ & $\begin{array}{c}0.013 * * * \\
(0.001)\end{array}$ & $\begin{array}{c}0.012^{* * *} \\
(0.001)\end{array}$ & $\begin{array}{c}0.011^{* * *} \\
(0.001)\end{array}$ \\
\hline US*dgap*2004 & $\begin{array}{c}0.017 * * * \\
(0.001)\end{array}$ & $\begin{array}{c}0.021^{* * *} \\
(0.001)\end{array}$ & $\begin{array}{c}0.019 * * * \\
(0.001)\end{array}$ & $\begin{array}{c}0.018^{* * *} \\
(0.001)\end{array}$ & $\begin{array}{c}0.012^{* * *} \\
(0.001)\end{array}$ & $\begin{array}{c}0.014 * * * \\
(0.001)\end{array}$ & $\begin{array}{c}0.012^{* * *} \\
(0.001)\end{array}$ & $\begin{array}{c}0.012^{* * *} \\
(0.001)\end{array}$ \\
\hline US*dgap*2005 & $\begin{array}{c}0.021^{* * *} \\
(0.001)\end{array}$ & $\begin{array}{c}0.022^{* * *} \\
(0.001)\end{array}$ & $\begin{array}{c}0.020 * * * \\
(0.001)\end{array}$ & $\begin{array}{c}0.019 * * * \\
(0.001)\end{array}$ & $\begin{array}{c}0.012 * * * \\
(0.001)\end{array}$ & $\begin{array}{c}0.014^{* * *} \\
(0.001)\end{array}$ & $\begin{array}{c}0.012 * * * \\
(0.001)\end{array}$ & $\begin{array}{c}0.012 * * * \\
(0.001)\end{array}$ \\
\hline US*dgap*2006 & $\begin{array}{c}0.020 * * * \\
(0.001)\end{array}$ & $\begin{array}{c}0.022^{* * *} \\
(0.001)\end{array}$ & $\begin{array}{c}0.019 * * * \\
(0.001)\end{array}$ & $\begin{array}{c}0.018^{* * *} \\
(0.001)\end{array}$ & $\begin{array}{c}0.012^{* * *} \\
(0.001)\end{array}$ & $\begin{array}{c}0.014^{* * *} \\
(0.001)\end{array}$ & $\begin{array}{c}0.013^{* * *} \\
(0.001)\end{array}$ & $\begin{array}{c}0.012^{* * *} \\
(0.001)\end{array}$ \\
\hline Constant & $\begin{array}{c}0.244^{* * *} \\
(0.001)\end{array}$ & $\begin{array}{c}0.244^{* * *} \\
(0.001)\end{array}$ & $\begin{array}{c}0.259 * * * \\
(0.001)\end{array}$ & $\begin{array}{c}0.264^{* * *} \\
(0.001)\end{array}$ & $\begin{array}{c}0.169 * * * \\
(0.001)\end{array}$ & $\begin{array}{c}0.169 * * * \\
(0.001)\end{array}$ & $\begin{array}{c}0.180 * * * \\
(0.001)\end{array}$ & $\begin{array}{c}0.183^{* * *} \\
(0.001)\end{array}$ \\
\hline HS6*Year FE & Yes & Yes & Yes & Yes & Yes & Yes & Yes & Yes \\
\hline $\begin{array}{l}\text { US*Year FE } \\
\text { X in US*Year*X }\end{array}$ & Yes & Yes & Yes & Yes & Yes & Yes & Yes & Yes \\
\hline $\begin{array}{l}\text { dat } \\
\text { avt } \\
\text { fixed_ass } \\
\text { imshare }\end{array}$ & Yes & $\begin{array}{l}\text { Yes } \\
\text { Yes }\end{array}$ & $\begin{array}{l}\text { Yes } \\
\text { Yes } \\
\text { Yes }\end{array}$ & $\begin{array}{l}\text { Yes } \\
\text { Yes } \\
\text { Yes } \\
\text { Yes }\end{array}$ & Yes & $\begin{array}{l}\text { Yes } \\
\text { Yes }\end{array}$ & $\begin{array}{l}\text { Yes } \\
\text { Yes } \\
\text { Yes }\end{array}$ & $\begin{array}{l}\text { Yes } \\
\text { Yes } \\
\text { Yes } \\
\text { Yes }\end{array}$ \\
\hline $\begin{array}{l}N \\
R^{2} \\
\text { adj. } R^{2} \\
\text { F }\end{array}$ & $\begin{array}{c}278446 \\
0.738 \\
0.738 \\
6138.980\end{array}$ & $\begin{array}{c}278446 \\
0.738 \\
0.738 \\
4646.850\end{array}$ & $\begin{array}{c}259476 \\
0.747 \\
0.747 \\
4083.272 \\
\end{array}$ & $\begin{array}{c}254968 \\
0.749 \\
0.749 \\
3520.625\end{array}$ & $\begin{array}{c}278446 \\
0.724 \\
0.724 \\
4309.669\end{array}$ & $\begin{array}{c}278446 \\
0.725 \\
0.725 \\
3249.056\end{array}$ & $\begin{array}{c}259476 \\
0.734 \\
0.734 \\
2689.484\end{array}$ & $\begin{array}{c}254968 \\
0.736 \\
0.736 \\
2264.383\end{array}$ \\
\hline
\end{tabular}


TABLE 6: Trade Policy Uncertainty and the Number of Firms, Difference in Differences Estimates: US comparison with the UK, Germany, France as Control Group

\begin{tabular}{|c|c|c|c|c|c|c|c|c|}
\hline \multirow[t]{2}{*}{ Dependent } & \multicolumn{4}{|c|}{$\begin{array}{c}\text { Log firm number in year t } \\
\text { new entrants (new exporter and adders) }\end{array}$} & \multicolumn{4}{|c|}{$\begin{array}{l}\text { Log firm number at year } 2000 \text { exited by year t } \\
\text { Exiters }\end{array}$} \\
\hline & $(1)$ & $(2)$ & (3) & $(4)$ & $(5)$ & (6) & $(7)$ & (8) \\
\hline US*dgap*2001 & $\begin{array}{c}0.009 * * * \\
(0.001)\end{array}$ & $\begin{array}{c}0.012^{* * *} \\
(0.001)\end{array}$ & $\begin{array}{l}0.010^{* * *} \\
(0.001)\end{array}$ & $\begin{array}{c}0.010^{* * *} \\
(0.001)\end{array}$ & $\begin{array}{c}0.010^{* * *} \\
(0.001)\end{array}$ & $\begin{array}{c}0.012^{* * *} \\
(0.001)\end{array}$ & $\begin{array}{c}0.011^{* * *} \\
(0.001)\end{array}$ & $\begin{array}{c}0.010 * * * \\
(0.001)\end{array}$ \\
\hline US*dgap*2002 & $\begin{array}{c}0.012 * * * \\
(0.001)\end{array}$ & $\begin{array}{c}0.014^{* * *} \\
(0.001)\end{array}$ & $\begin{array}{c}0.013^{* * *} \\
(0.001)\end{array}$ & $\begin{array}{c}0.012^{* * *} \\
(0.001)\end{array}$ & $\begin{array}{c}0.010^{* * *} \\
(0.001)\end{array}$ & $\begin{array}{c}0.011^{* * *} \\
(0.001)\end{array}$ & $\begin{array}{c}0.010 * * * \\
(0.001)\end{array}$ & $\begin{array}{c}0.010^{* * *} \\
(0.001)\end{array}$ \\
\hline US*dgap*2003 & $\begin{array}{c}0.012 * * * \\
(0.001)\end{array}$ & $\begin{array}{c}0.015^{* * *} \\
(0.001)\end{array}$ & $\begin{array}{c}0.013^{* * *} \\
(0.001)\end{array}$ & $\begin{array}{c}0.013^{* * *} \\
(0.001)\end{array}$ & $\begin{array}{c}0.009 * * * \\
(0.001)\end{array}$ & $\begin{array}{c}0.011^{* * *} \\
(0.001)\end{array}$ & $\begin{array}{c}0.010 * * * \\
(0.001)\end{array}$ & $\begin{array}{c}0.009 * * * \\
(0.001)\end{array}$ \\
\hline US*dgap*2004 & $\begin{array}{c}0.013 * * * \\
(0.001)\end{array}$ & $\begin{array}{c}0.017 * * * \\
(0.001)\end{array}$ & $\begin{array}{c}0.015^{* * *} \\
(0.001)\end{array}$ & $\begin{array}{c}0.014^{* * *} \\
(0.001)\end{array}$ & $\begin{array}{c}0.010^{* * *} \\
(0.001)\end{array}$ & $\begin{array}{c}0.012^{* * *} \\
(0.001)\end{array}$ & $\begin{array}{c}0.010^{* * *} \\
(0.001)\end{array}$ & $\begin{array}{c}0.010^{* * *} \\
(0.001)\end{array}$ \\
\hline US*dgap*2005 & $\begin{array}{c}0.016 * * * \\
(0.001)\end{array}$ & $\begin{array}{c}0.018^{* * *} \\
(0.001)\end{array}$ & $\begin{array}{c}0.016 * * * \\
(0.001)\end{array}$ & $\begin{array}{c}0.015^{* * *} \\
(0.001)\end{array}$ & $\begin{array}{c}0.009 * * * \\
(0.001)\end{array}$ & $\begin{array}{c}0.011^{* * *} \\
(0.001)\end{array}$ & $\begin{array}{c}0.010^{* * *} \\
(0.001)\end{array}$ & $\begin{array}{c}0.010^{* * *} \\
(0.001)\end{array}$ \\
\hline US*dgap*2006 & $\begin{array}{c}0.015^{* * *} \\
(0.001)\end{array}$ & $\begin{array}{c}0.016^{* * *} \\
(0.001)\end{array}$ & $\begin{array}{c}0.014^{* * *} \\
(0.001)\end{array}$ & $\begin{array}{c}0.013^{* * *} \\
(0.001)\end{array}$ & $\begin{array}{c}0.010^{* * *} \\
(0.001)\end{array}$ & $\begin{array}{c}0.012^{* * *} \\
(0.001)\end{array}$ & $\begin{array}{c}0.011^{* * *} \\
(0.001)\end{array}$ & $\begin{array}{c}0.010^{* * *} \\
(0.001)\end{array}$ \\
\hline Constant & $\begin{array}{c}0.455^{* * *} \\
(0.002)\end{array}$ & $\begin{array}{c}0.455^{* * *} \\
(0.002)\end{array}$ & $\begin{array}{c}0.485^{* * *} \\
(0.002)\end{array}$ & $\begin{array}{c}0.493 * * * \\
(0.002)\end{array}$ & $\begin{array}{c}0.319 * * * \\
(0.002)\end{array}$ & $\begin{array}{c}0.319 * * * \\
(0.002)\end{array}$ & $\begin{array}{c}0.339 * * * \\
(0.002)\end{array}$ & $\begin{array}{c}0.345 * * * \\
(0.002)\end{array}$ \\
\hline HS6*Year FE & Yes & Yes & Yes & Yes & Yes & Yes & Yes & Yes \\
\hline $\begin{array}{l}\text { US*Year FE } \\
\mathrm{X} \text { in US*Year*X }\end{array}$ & Yes & Yes & Yes & Yes & Yes & Yes & Yes & Yes \\
\hline $\begin{array}{l}\text { dat } \\
\text { avt } \\
\text { fixed_ass } \\
\text { imshare }\end{array}$ & Yes & $\begin{array}{l}\text { Yes } \\
\text { Yes }\end{array}$ & $\begin{array}{l}\text { Yes } \\
\text { Yes } \\
\text { Yes }\end{array}$ & $\begin{array}{l}\text { Yes } \\
\text { Yes } \\
\text { Yes } \\
\text { Yes }\end{array}$ & Yes & $\begin{array}{l}\text { Yes } \\
\text { Yes }\end{array}$ & $\begin{array}{l}\text { Yes } \\
\text { Yes } \\
\text { Yes }\end{array}$ & $\begin{array}{l}\text { Yes } \\
\text { Yes } \\
\text { Yes } \\
\text { Yes }\end{array}$ \\
\hline $\begin{array}{l}N \\
R^{2} \\
\text { adj. } R^{2} \\
\text { F }\end{array}$ & $\begin{array}{c}79556 \\
0.864 \\
0.864 \\
6601.847\end{array}$ & $\begin{array}{c}79556 \\
0.865 \\
0.865 \\
5032.622\end{array}$ & $\begin{array}{c}74136 \\
0.874 \\
0.874 \\
4378.683\end{array}$ & $\begin{array}{c}72848 \\
0.876 \\
0.876 \\
3774.275\end{array}$ & $\begin{array}{c}79556 \\
0.830 \\
0.830 \\
4567.925\end{array}$ & $\begin{array}{c}79556 \\
0.831 \\
0.831 \\
3456.139\end{array}$ & $\begin{array}{c}74136 \\
0.839 \\
0.839 \\
2840.160\end{array}$ & $\begin{array}{c}72848 \\
0.841 \\
0.841 \\
2393.718\end{array}$ \\
\hline
\end{tabular}

Notes: Standard errors in () are clustered at HS 6digit level. The change in tariff uncertainty is labelled with (dgap). Coefficients for the triple interaction with (dgap) by year (2001-2006) are reported, while other variables are suppressed. The average applied import tariff is given by (avt), and the change in the applied tariffs is given by (dat). Industry fixed_assets relative to sales is measured by (fixed_ass), while the intermediary share of trade at the 6-digit level is given by (imshare). Statistical significance denoted by: $\quad$ b p $\quad<\quad 0.10, \quad * * \quad \mathrm{p}<0.05, \quad<* * \quad \mathrm{p}, 0.01$. 
Table 7: Aggregate Price Changes at the 6-digit Product Level

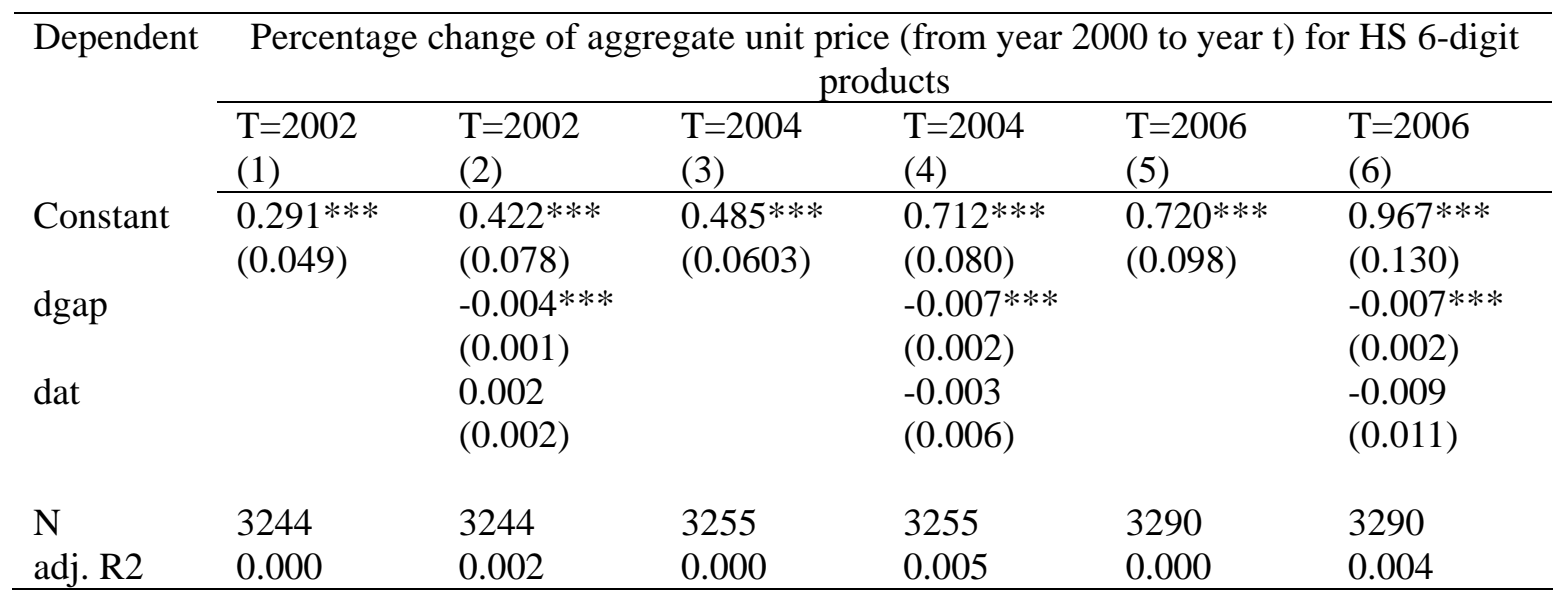

Notes: The change in tariff uncertainty is labelled with (dgap), while the change in the applied tariffs is given by (dat). Statistical significance denoted by: ${ }^{*} \mathrm{p}<0.10$, ${ }^{* *} \mathrm{p}<0.05$, ${ }^{* * *} \mathrm{p}<0.01$.

Table 8: Price Difference between New Exporters and Exiters

\begin{tabular}{|c|c|c|c|c|c|c|}
\hline \multirow[t]{3}{*}{ Dependent } & \multicolumn{6}{|c|}{ Ln (Unit price) in year t (for new exporters) or in year 2000 (for exiters) } \\
\hline & \multicolumn{2}{|c|}{$\mathrm{T}=2002$} & \multicolumn{2}{|c|}{$\mathrm{T}=2004$} & \multicolumn{2}{|c|}{$\mathrm{T}=2006$} \\
\hline & (1) & $(2)$ & (3) & (4) & $(5)$ & $(6)$ \\
\hline NewExp & - & $0.114 * * *$ & $0.042 * * *$ & $0.346 * * *$ & $0.180 * * *$ & $0.584 * * *$ \\
\hline & $\begin{array}{c}0.107 * * * \\
(0.006)\end{array}$ & $(0.016)$ & $(0.005)$ & $(0.013)$ & $(0.004)$ & $(0.012)$ \\
\hline NewExp*dgap & & $\begin{array}{c}-0.002^{* * *} \\
(0.000)\end{array}$ & & $\begin{array}{c}-0.003^{* * *} \\
(0.000)\end{array}$ & & $\begin{array}{c}-0.005^{* * * *} \\
(0.000)\end{array}$ \\
\hline NewExp*dat & & $\begin{array}{c}0.004 \\
(0.004)\end{array}$ & & $\begin{array}{l}-0.004 \\
(0.004)\end{array}$ & & $\begin{array}{c}-0.017^{* * *} \\
(0.004)\end{array}$ \\
\hline Constant & $\begin{array}{c}0.946 * * * \\
(0.004)\end{array}$ & $\begin{array}{c}0.911 * * * \\
(0.005)\end{array}$ & $\begin{array}{c}0.972 * * * \\
(0.004)\end{array}$ & $\begin{array}{c}0.943 * * * \\
(0.004)\end{array}$ & $\begin{array}{c}1.012 * * * \\
(0.004)\end{array}$ & $\begin{array}{c}0.994 * * * \\
(0.004)\end{array}$ \\
\hline HS 6-digit FE & Yes & Yes & Yes & Yes & Yes & Yes \\
\hline Ownership FE & No & Yes & No & Yes & No & Yes \\
\hline $\mathrm{N}$ & 149561 & 149561 & 274347 & 274347 & 448174 & 448174 \\
\hline adj. R2 & 0.561 & 0.573 & 0.559 & 0.570 & 0.547 & 0.559 \\
\hline
\end{tabular}

Notes: The change in tariff uncertainty is labeled with (dgap), while the change in the applied tariffs is given by (dat). New export transactions are denoted by an indicator variable (NewExp). Statistical significance denoted by: ${ }^{*} \mathrm{p}<0.10,{ }^{* *} \mathrm{p}<0.05,{ }^{* * *} \mathrm{p}<0.01$. 
Table 9: Quality Difference between New Exporters and Exiters

\begin{tabular}{|c|c|c|c|c|c|c|}
\hline \multirow[t]{3}{*}{ Dependent } & \multicolumn{6}{|c|}{ Quality in year t (for new exporters) or in year 2000 (for exiters) } \\
\hline & \multicolumn{2}{|c|}{$\mathrm{T}=2002$} & \multicolumn{2}{|c|}{$\mathrm{T}=2004$} & \multicolumn{2}{|c|}{$\mathrm{T}=2006$} \\
\hline & $(1)$ & $(2)$ & (3) & $(4)$ & $(5)$ & $(6)$ \\
\hline NewExp & $\begin{array}{c}0.261 * * * \\
(0.012)\end{array}$ & $\begin{array}{c}0.369 * * * \\
(0.030)\end{array}$ & $\begin{array}{c}0.161 * * * \\
(0.009)\end{array}$ & $\begin{array}{c}0.383 * * * \\
(0.024)\end{array}$ & $\begin{array}{c}0.087 * * * \\
(0.008)\end{array}$ & $\begin{array}{c}0.432 * * * \\
(0.022)\end{array}$ \\
\hline NewExp*dgap & & $\begin{array}{c}-0.000 \\
(0.001)\end{array}$ & & $\begin{array}{l}-0.000 \\
(0.001)\end{array}$ & & $\begin{array}{c}0.000 \\
(0.000)\end{array}$ \\
\hline NewExp*dat & & $\begin{array}{c}-0.001 \\
(0.009)\end{array}$ & & $\begin{array}{c}-0.008 \\
(0.007)\end{array}$ & & $\begin{array}{c}-0.014^{* *} \\
(0.007)\end{array}$ \\
\hline Constant & $\begin{array}{c}-0.569 * * * \\
(0.008)\end{array}$ & $\begin{array}{c}-0.640 * * * \\
(0.009)\end{array}$ & $\begin{array}{c}-0.348^{* * *} \\
(0.007)\end{array}$ & $\begin{array}{c}-0.437^{* * *} \\
(0.008)\end{array}$ & $\begin{array}{c}-0.232 * * * \\
(0.007)\end{array}$ & $\begin{array}{c}-0.315^{* * *} \\
(0.008)\end{array}$ \\
\hline HS 6digit FE & Yes & Yes & Yes & Yes & Yes & Yes \\
\hline Ownership FE & No & Yes & No & Yes & No & Yes \\
\hline $\mathrm{N}$ & 147640 & 147640 & 271508 & 271508 & 443497 & 443497 \\
\hline $\mathrm{R} 2$ & 0.024 & 0.033 & 0.009 & 0.027 & 0.004 & 0.028 \\
\hline adj. R2 & 0.005 & 0.015 & -0.002 & 0.017 & -0.003 & 0.022 \\
\hline Log lik. & $-3.22 \mathrm{e}+05$ & $-3.22 \mathrm{e}+05$ & $-6.08 \mathrm{e}+05$ & $-6.05 e+05$ & $-9.99 e+05$ & $-9.94 e+05$ \\
\hline $\mathrm{F}$ & 496.831 & 240.543 & 290.948 & 589.570 & 108.331 & 1234.143 \\
\hline
\end{tabular}




\section{Appendix}

\section{A1 Proof of existence and uniqueness of equilibrium solution}

We can rewrite the ZCP and FE conditions as $j\left(\varphi^{*}\right)=\frac{(1-\rho) f_{e}}{M^{\eta} f}$, where $j(\varphi) \equiv\left[\left(\frac{\widetilde{\varphi}(\varphi)}{\varphi}\right)^{\sigma-1}-\right.$ 1][1-G( $\varphi)$ ]. As shown by Melitz (2003), $j(\varphi)$ goes from $\infty$ to 0 when $\varphi$ goes from 0 to $\infty$. This proves the existence and uniqueness of the solution $\varphi^{*}$ and $\bar{\pi}_{p}$ for any given value of $M$. This property of $j(\varphi)$ also necessarily implies that the solutions of $\varphi^{*}$ and $\bar{\pi}_{p}$ are increasing functions of $M$. Specifically, when $M$ goes to infinity, $\varphi^{*}(M)$ goes to infinity. When $M$ goes to zero, $\varphi^{*}(M)$ goes to zero. The same applies to $\bar{\pi}_{p}(M)$.

\section{A2 Derivation of estimating equation (16)}

The full empirical specification is as follows:

$$
\begin{gathered}
\text { lnEXNum }_{\text {m } h \mathrm{ct}}=\alpha+\sum_{j=2001}^{2006} \beta_{j} 1\{j=t\} 1\{c=u s\} d g a p_{h} \\
+\sum_{j=2001}^{2006} \gamma_{j} 1\{j=t\} 1\{c=u s\} X_{h} \\
+\sum_{j=2001}^{2006} \delta_{j} 1\{j=t\} 1\{c=u s\}+\sum_{j=2001}^{2006} \delta_{2 j} 1\{j=t\}+\sum_{j=2001}^{2006} \delta_{3 j} 1\{j=t\} d g a p_{h} \\
+\sum_{j=2001}^{2006} \delta_{4 j} 1\{j=t\} X_{h}+\delta_{5} 1\{c=u s\} d g a p_{h}+\delta_{6} 1\{c=u s\} X_{h}+\delta_{c h}+\delta_{h t}+\varepsilon_{h c t}
\end{gathered}
$$

Note we have included very comprehensive fixed effects: product*year fixed effects and country*product fixed effects.

Further note that the product*year fixed effects, $\delta_{h t}$, absorb the terms $\sum_{j=2001}^{2006} \delta_{2 j} 1\{j=t\}$, $\sum_{j=2001}^{2006} \delta_{3 j} 1\{j=t\} \operatorname{dgap}_{h}$ and $\sum_{j=2001}^{2006} \delta_{4 j} 1\{j=t\} X_{h}$. Similarly, the terms $\delta_{5} 1\{c=$ $u s\} d g a p_{h}, \delta_{6} 1\{c=u s\} X_{h}$ are absorbed by the country*product fixed effects, $\delta_{c h}$. Thus, we can simplify the estimation equation as:

$$
\begin{aligned}
& \operatorname{lnEXNum}_{\mathrm{m} h \mathrm{ct}}=\alpha+\sum_{j=2001}^{2006} \beta_{j} 1\{j=t\} 1\{c=u s\} d_{\text {gap }} \\
&+\sum_{j=2001}^{2006} \gamma_{j} 1\{j=t\} 1\{c=u s\} X_{h} \\
&+\sum_{j=2001}^{2006} \delta_{j} 1\{j=t\} 1\{c=u s\}+\delta_{c h}+\delta_{h t}+\varepsilon_{h c t}
\end{aligned}
$$


Taking differences across periods, the equation can then be written as

$$
\begin{gathered}
\operatorname{dlnEXNum}_{\mathrm{m} h \mathrm{ct}}=\sum_{j=2001}^{2006} \beta_{j} 1\{j=t\} 1\{c=u s\} d g a p_{h}+\sum_{j=2001}^{2006} \gamma_{j} 1\{j=t\} 1\{c=u s\} X_{h} \\
+\sum_{j=2001}^{2006} \delta_{j} 1\{j=t\} 1\{c=u s\}+\delta_{h t}^{\prime}+\varepsilon_{h c t}^{\prime}
\end{gathered}
$$

which is estimation equation (16).

\section{A3 Import structure similarity}

We construct the import similarity index based on the approach of Finger and Kreinin (1979). We first calculate the import share of product $h$ in a country c's total imports from China in year $t$, $s_{h c t}=E X_{h c t} /\left(\sum_{h} E X_{h c t}\right)$. We then construct the similarity index by comparing these shares to the shares in the reference country, which is US in our case, $S I_{c t}=100 \sum_{h} \min \left(s_{h c t}, s_{h t}^{U S}\right)$. This index is bounded by zero and one hundred, with higher values indicate higher similarity. Appendix Table 4 shows the similarity index for the EU countries.

\section{A4 Adders vs Exiters}

In this section, we compare prices and qualities of adders against those of exiting exporters. The estimation equation and approach are similar to those in text when we compare new exporters and exiters.

Appendix Table 5 reports the results comparing adders' price with exiters' price. As shown by columns 1 , unlike new exporters in year 2002, adders on average charged higher prices in 2002 than did exiters in 2000. For years 2004 and 2006, we also find adders charged higher prices in these years than the exiters' price in 2000. For year 2002 and 2004 (columns 2 and 4), we do not find that the price difference between adders and exiters was significantly correlated with uncertainty reduction, though we do find negative significant correlation in year 2006.

Appendix Table 6 reports the quality results comparing adders against exiters. As shown by columns 1, 3 and 5, we find that adders on average have higher quality than exiters in all years. Moreover, for years 2004 and 2006 (columns 4 and 6), we find that the quality difference between adders and exiters are significantly larger if the product experienced higher uncertainty reduction.

Overall, although we do not find strong evidence that adders charged lower prices than exiters, we do find that they export goods with higher qualities than the exiters. Moreover, we

find some evidence that the price and quality premium of adders relative to exporting exiters were related to the products' uncertainty reduction. 


\section{A5 Productivity Comparison of New Exporters and Exiters}

We estimate manufacturing firms' TFP based on the Chinese Manufacturing census, following Feenstra, Li and Yu (2014). We then matched the firms in the Chinese Manufacturing census with the firms in the Customs dataset. Details of the matching procedure can be found in Feng, Li and Swenson (2012). Since we only have one productivity measure for each firm, we assign this productivity to each product exported by the firm. We thus have firm*product level information of firm productivity for new exporters in the years (2002, 2004 and 2006) and for exiters in the year (2000). Note, since all nominal values are deflated when we estimate firm TFP, productivity measures in different years are comparable. Note also that we maintain the dataset at firm*product level in order to compare productivities of firms that were exporting the same HS 6digit products.

For the pooled sample of new exporters and exporting exiters, we regress the productivity measure, our TFP estimate, on the new exporter dummy and its interactions with our measure of uncertainty reductions and/or with the applied tariff reductions. The specification for this regression is identical to Eq. (17), but with the dependent variable replaced by the productivity measure.

Appendix Table 7 displays the productivity regression results. Columns 1, 3 and 5 show that, for exporters which exported the same HS 6-digit products, the productivity of new exporters exceeded the productivity of exiters in 2004 and 2006, but not immediately after WTO accession in 2002. In columns 2, 4 and 6 we do not find that the magnitude of the productivity premium of new exporters was related to the magnitude of the trade policy uncertainty reductions. 


\section{APPENDIX TABLES}

\section{Appendix Table 1: Market Share Changes 2000-2002, Overall and by Firm Ownership}

\begin{tabular}{|c|c|c|c|c|}
\hline Margin & $\begin{array}{l}\text { All } \\
\text { (1) }\end{array}$ & $\begin{array}{l}\text { SOE } \\
(2)\end{array}$ & $\begin{array}{l}\text { FIE } \\
\text { (3) }\end{array}$ & $\begin{array}{l}\text { Dom } \\
\text { (4) }\end{array}$ \\
\hline (1) Incumbents & $-6.479 * * *$ & $-3.808 * * *$ & $-2.677 * * *$ & 0.006 \\
\hline \multicolumn{5}{|l|}{ Net entry } \\
\hline (2) Exiters & $-53.489 * * *$ & $-38.069 * * *$ & $-12.418^{* * *}$ & $-3.002 * * *$ \\
\hline New Exporters & $25.845^{* * *}$ & $8.826 * * *$ & $10.196 * * *$ & $6.824 * * *$ \\
\hline (4) Adders & $34.123^{* * *}$ & $24.756^{* * *}$ & $6.812^{* * *}$ & $2.555 * * *$ \\
\hline (5) Total Net Entry & $6.479 * * *$ & $-4.487 * * *$ & $4.589 * * *$ & $6.377 * * *$ \\
\hline (6) Total & 0 & $-8.295 * * *$ & $1.912^{* * *}$ & $6.383 * * *$ \\
\hline
\end{tabular}

Note: This table reports the average market share changes for different margins for the period from 2000 to 2002.

\section{Appendix Table 2: Sectors in HS Classification}

\begin{tabular}{llllll}
\hline Sector Name & HS 2 digit & Sector Name & HS 2 digit & Sector Name & HS 2 digit \\
\hline Food & $1-24$ & Paper & $47-49$ & Machinery & $84-85$ \\
Minerals & $25-27$ & Textiles & $50-63$ & Vehicles & $86-89$ \\
Chemicals & $28-38$ & Footwear & $64-67$ & Instruments & $90-92$ \\
Plastics & $39-40$ & Ceramics & $68-70$ & Arms & 93 \\
Leather & $41-43$ & Jewelry & 71 & Toys & $94-96$ \\
Wood & $44-46$ & Iron & $72-83$ & Arts & 97 \\
\hline
\end{tabular}


Appendix Table 3: Trade Policy and Number of Firms: New Exporters, Adders and Exiters, Sample excluding the Textile, Machinery and Instrument Industries

\begin{tabular}{|c|c|c|c|c|c|c|c|c|c|}
\hline \multirow[t]{2}{*}{ Dependent } & \multicolumn{3}{|c|}{$\begin{array}{c}\text { Log firm number (year t) } \\
\text { new exporters }\end{array}$} & \multicolumn{3}{|c|}{$\begin{array}{c}\text { Log firm number (year t) } \\
\text { adders }\end{array}$} & \multicolumn{3}{|c|}{$\begin{array}{l}\text { Log firm number (year 2000) } \\
\text { exiters (exit by year t) }\end{array}$} \\
\hline & $\begin{array}{c}\mathrm{T}=2002 \\
(1)\end{array}$ & $\begin{array}{c}\mathrm{T}=2004 \\
(2)\end{array}$ & $\begin{array}{c}\mathrm{T}=2006 \\
(3)\end{array}$ & $\begin{array}{c}\mathrm{T}=2002 \\
(4)\end{array}$ & $\begin{array}{c}\mathrm{T}=2004 \\
(5)\end{array}$ & $\begin{array}{c}\mathrm{T}=2006 \\
(6)\end{array}$ & $\begin{array}{c}\mathrm{T}=2002 \\
(7)\end{array}$ & $\begin{array}{c}\mathrm{T}=2004 \\
(8)\end{array}$ & $\begin{array}{c}\mathrm{T}=2006 \\
(9)\end{array}$ \\
\hline dgap & $\begin{array}{l}0.016^{* * *} \\
(0.005)\end{array}$ & $\begin{array}{l}0.019 * * * \\
(0.005)\end{array}$ & $\begin{array}{l}0.020 * * * \\
(0.005)\end{array}$ & $\begin{array}{l}0.017 * * * \\
(0.005)\end{array}$ & $\begin{array}{l}0.016^{* * *} \\
(0.005)\end{array}$ & $\begin{array}{l}0.015^{* * *} \\
(0.004)\end{array}$ & $\begin{array}{l}0.017^{* * *} \\
(0.004)\end{array}$ & $\begin{array}{l}0.018 * * * \\
(0.004)\end{array}$ & $\begin{array}{l}0.017 * * * \\
(0.004)\end{array}$ \\
\hline dat & $\begin{array}{l}-0.000 \\
(0.022)\end{array}$ & $\begin{array}{l}0.007 \\
(0.023)\end{array}$ & $\begin{array}{l}0.015 \\
(0.021)\end{array}$ & $\begin{array}{l}0.007 \\
(0.022)\end{array}$ & $\begin{array}{l}0.016 \\
(0.019)\end{array}$ & $\begin{array}{l}0.018 \\
(0.016)\end{array}$ & $\begin{array}{l}-0.002 \\
(0.022)\end{array}$ & $\begin{array}{l}-0.002 \\
(0.023)\end{array}$ & $\begin{array}{l}-0.001 \\
(0.023)\end{array}$ \\
\hline avt & $\begin{array}{l}-0.002 \\
(0.016)\end{array}$ & $\begin{array}{l}0.000 \\
(0.017)\end{array}$ & $\begin{array}{l}0.007 \\
(0.017)\end{array}$ & $\begin{array}{l}-0.003 \\
(0.016)\end{array}$ & $\begin{array}{l}0.005 \\
(0.015)\end{array}$ & $\begin{array}{l}0.005 \\
(0.014)\end{array}$ & $\begin{array}{l}-0.004 \\
(0.017)\end{array}$ & $\begin{array}{l}-0.003 \\
(0.018)\end{array}$ & $\begin{array}{l}-0.002 \\
(0.018)\end{array}$ \\
\hline fixed_ass & $\begin{array}{l}-0.632^{* * *} \\
(0.132)\end{array}$ & $\begin{array}{l}-0.806 * * * \\
(0.166)\end{array}$ & $\begin{array}{l}-0.807^{* * *} \\
(0.175)\end{array}$ & $\begin{array}{l}-0.649 * * * \\
(0.152)\end{array}$ & $\begin{array}{l}-0.710^{* * *} \\
(0.135)\end{array}$ & $\begin{array}{l}-0.643^{* * *} \\
(0.151)\end{array}$ & $\begin{array}{l}-0.651^{* * *} \\
(0.159)\end{array}$ & $\begin{array}{l}-0.659 * * * \\
(0.161)\end{array}$ & $\begin{array}{l}-0.671^{* * *} \\
(0.166)\end{array}$ \\
\hline imshare & $\begin{array}{l}-0.067 \\
(0.128)\end{array}$ & $\begin{array}{l}-0.278^{*} \\
(0.158)\end{array}$ & $\begin{array}{l}-0.391 * * \\
(0.166)\end{array}$ & $\begin{array}{l}-0.105 \\
(0.135)\end{array}$ & $\begin{array}{l}-0.131 \\
(0.125)\end{array}$ & $\begin{array}{l}-0.151 \\
(0.120)\end{array}$ & $\begin{array}{l}-0.057 \\
(0.144)\end{array}$ & $\begin{array}{l}-0.083 \\
(0.156)\end{array}$ & $\begin{array}{l}-0.055 \\
(0.154)\end{array}$ \\
\hline Constant & $\begin{array}{l}1.496 * * * \\
(0.146)\end{array}$ & $\begin{array}{l}2.203^{* * * *} \\
(0.159)\end{array}$ & $\begin{array}{l}2.659 * * * \\
(0.175)\end{array}$ & $\begin{array}{l}1.698 * * * \\
(0.135)\end{array}$ & $\begin{array}{l}1.664^{* * *} \\
(0.135)\end{array}$ & $\begin{array}{l}1.597 * * * \\
(0.137)\end{array}$ & $\begin{array}{l}1.807^{* * * *} \\
(0.136)\end{array}$ & $\begin{array}{l}1.927^{* * *} \\
(0.146)\end{array}$ & $\begin{array}{l}1.966^{* * *} \\
(0.145)\end{array}$ \\
\hline HS 2d FE & Yes & Yes & Yes & Yes & Yes & Yes & Yes & Yes & Yes \\
\hline $\mathrm{N}$ & 2124 & 2124 & 2124 & 2124 & 2124 & 2124 & 2124 & 2124 & 2124 \\
\hline adj. R2 & 0.343 & 0.357 & 0.354 & 0.363 & 0.366 & 0.371 & 0.357 & 0.350 & 0.351 \\
\hline $\mathrm{F}$ & 8.830 & 10.996 & 11.656 & 9.155 & 12.383 & 10.689 & 7.574 & 7.895 & 7.605 \\
\hline
\end{tabular}

Note: This table reports regression results based on the exclusion of the textile, apparel, machinery and instrument sectors from our full sample. Standard errors in () are clustered at HS 2digit level. The change in tariff uncertainty is labelled with ( $\mathrm{dgap}$ ), while the average applied import tariff is given by (avt), and the change in the applied tariffs is given by (dat). Industry fixed_assets relative to sales is measured by (fixed_ass), while the intermediary share of trade at the 6-digit level is given by (imshare). Statistical significance denoted by: * $\mathrm{p}<0.10,{ }^{* *} \mathrm{p}<0.05, * * * \mathrm{p}<0.01$. 
Appendix Table 4: Import Similarity Index for EU Countries with the U.S.

\begin{tabular}{llllll}
\hline Country & Similarity & Country & Similarity & Country & Similarity \\
\hline United Kingdom & .71 & Sweden & .52 & Finland & .48 \\
Germany & .64 & Austria & .52 & Denmark & .46 \\
France & .64 & Belgium & .50 & Greece & .46 \\
Spain & .56 & Italy & .50 & Ireland & .33 \\
Netherlands & .55 & Portugal & .49 & Luxembourg & .17 \\
\hline
\end{tabular}

Note: method for computing import similarity indices described in A3.

\section{Appendix Table 5: Price Difference between Adders and Exiters}

\begin{tabular}{|c|c|c|c|c|c|c|}
\hline \multirow[t]{3}{*}{ Dependent } & \multicolumn{6}{|c|}{ Ln (Unit price) in year t (for adders) or in year 2000 (for exiters) } \\
\hline & \multicolumn{2}{|c|}{$\mathrm{T}=2002$} & \multicolumn{2}{|c|}{$\mathrm{T}=2004$} & \multicolumn{2}{|c|}{$\mathrm{T}=2006$} \\
\hline & $(1)$ & $(2)$ & $(3)$ & $(4)$ & (5) & $(6)$ \\
\hline Adder & $\begin{array}{c}0.055 * * * \\
(0.006)\end{array}$ & $\begin{array}{c}0.053^{* * * *} \\
(0.016)\end{array}$ & $\begin{array}{c}0.191^{* * *} \\
(0.006)\end{array}$ & $\begin{array}{c}0.212^{* * *} \\
(0.015)\end{array}$ & $\begin{array}{c}0.385^{* * *} \\
(0.006)\end{array}$ & $\begin{array}{c}0.488 * * * \\
(0.015)\end{array}$ \\
\hline Adder*dgap & & $\begin{array}{c}0.000 \\
(0.000)\end{array}$ & & $\begin{array}{l}-0.000 \\
(0.000)\end{array}$ & & $\begin{array}{c}-0.002 * * * \\
(0.000)\end{array}$ \\
\hline Adder*dat & & $\begin{array}{l}-0.001 \\
(0.004)\end{array}$ & & $\begin{array}{c}-0.011^{* *} \\
(0.005)\end{array}$ & & $\begin{array}{c}-0.038 * * * \\
(0.006)\end{array}$ \\
\hline Constant & $\begin{array}{c}0.983 * * * \\
(0.004)\end{array}$ & $\begin{array}{c}0.946^{* * *} \\
(0.005)\end{array}$ & $\begin{array}{c}1.002 * * * \\
(0.004)\end{array}$ & $\begin{array}{c}0.964^{* * *} \\
(0.004)\end{array}$ & $\begin{array}{c}1.027 * * * \\
(0.004)\end{array}$ & $\begin{array}{c}0.988 * * * \\
(0.004)\end{array}$ \\
\hline HS 6d FE & Yes & Yes & Yes & Yes & Yes & Yes \\
\hline $\begin{array}{l}\text { Ownership } \\
\text { FE }\end{array}$ & Yes & Yes & Yes & Yes & Yes & Yes \\
\hline $\mathrm{N}$ & 158373 & 158373 & 177996 & 177996 & 186350 & 186350 \\
\hline adj. R2 & 0.545 & 0.548 & 0.557 & 0.559 & 0.566 & 0.569 \\
\hline
\end{tabular}

Notes: The indicator variable, Adder, is set to one for all new product exports that were added by existing exporters of other products. Notes: The change in tariff uncertainty is labeled with (dgap), while the change in the applied tariffs is given by (dat). Statistical significance denoted by: $* \mathrm{p}<0.10,{ }^{* *} \mathrm{p}<0.05$, *** $\mathrm{p}<0.01$. 


\section{Appendix Table 6: Quality Difference between Adders and Exiters}

\begin{tabular}{|c|c|c|c|c|c|c|}
\hline \multirow{3}{*}{$\begin{array}{l}\text { Dependent } \\
\text { Variable }\end{array}$} & \multicolumn{6}{|c|}{ Quality in year t (for adders) or in year 2000 (for exiters) } \\
\hline & \multicolumn{2}{|c|}{$\mathrm{T}=2002$} & \multicolumn{2}{|c|}{$\mathrm{T}=2004$} & \multicolumn{2}{|c|}{$\mathrm{T}=2006$} \\
\hline & $(1)$ & $(2)$ & (3) & $(4)$ & $(5)$ & $(6)$ \\
\hline Adder & $\begin{array}{c}0.052 * * * \\
(0.011)\end{array}$ & $\begin{array}{c}0.048 * \\
(0.028)\end{array}$ & $\begin{array}{c}0.112^{* * *} \\
(0.012)\end{array}$ & $\begin{array}{c}0.063 * * \\
(0.029)\end{array}$ & $\begin{array}{c}0.298 * * * \\
(0.012)\end{array}$ & $\begin{array}{c}0.238 * * * \\
(0.030)\end{array}$ \\
\hline Adder*dgap & & $\begin{array}{c}0.000 \\
(0.001)\end{array}$ & & $\begin{array}{l}0.001 * \\
(0.001)\end{array}$ & & $\begin{array}{c}0.001^{* *} \\
(0.001)\end{array}$ \\
\hline Adder*dat & & $\begin{array}{l}-0.007 \\
(0.008)\end{array}$ & & $\begin{array}{l}-0.012 \\
(0.009)\end{array}$ & & $\begin{array}{l}-0.015 \\
(0.012)\end{array}$ \\
\hline Constant & $\begin{array}{c}-0.543 * * * \\
(0.008)\end{array}$ & $\begin{array}{c}-0.572 * * * \\
(0.009)\end{array}$ & $\begin{array}{c}-0.333^{* * *} \\
(0.007)\end{array}$ & $\begin{array}{c}-0.386 * * * \\
(0.008)\end{array}$ & $\begin{array}{c}-0.232 * * * \\
(0.007)\end{array}$ & $\begin{array}{c}-0.291 * * * \\
(0.008)\end{array}$ \\
\hline HS 6d FE & Yes & Yes & Yes & Yes & Yes & Yes \\
\hline $\begin{array}{l}\text { Ownership } \\
\text { FE }\end{array}$ & Yes & Yes & Yes & Yes & Yes & Yes \\
\hline $\mathrm{N}$ & 156070 & 156070 & 175676 & 175676 & 183805 & 183805 \\
\hline $\begin{array}{l}\text { Log lik. } \\
\text { adj. R2 }\end{array}$ & $\begin{array}{c}-3.41 e+05 \\
0.006\end{array}$ & $\begin{array}{c}-3.41 e+05 \\
0.007\end{array}$ & $\begin{array}{c}-3.91 e+05 \\
-0.001\end{array}$ & $\begin{array}{c}-3.91 \mathrm{e}+05 \\
0.001\end{array}$ & $\begin{array}{c}-4.11 \mathrm{e}+05 \\
0.000\end{array}$ & $\begin{array}{c}-4.11 \mathrm{e}+05 \\
0.002\end{array}$ \\
\hline
\end{tabular}

\section{Appendix Table 7: Productivity Difference between New Exporters and Exiters}

\begin{tabular}{|c|c|c|c|c|c|c|}
\hline \multirow[t]{3}{*}{ Dependent } & \multicolumn{6}{|c|}{ Productivity (TFP) in year t (for new exporters) or in year 2000 (for exiters) } \\
\hline & \multicolumn{2}{|c|}{$\mathrm{T}=2002$} & \multicolumn{2}{|c|}{$\mathrm{T}=2004$} & \multicolumn{2}{|c|}{$\mathrm{T}=2006$} \\
\hline & $(1)$ & $(2)$ & (3) & $(4)$ & $(5)$ & $(6)$ \\
\hline \multirow[t]{2}{*}{ NewExp } & 0.006 & 0.025 & $0.034 * * *$ & $0.080 * * *$ & $0.034 * * *$ & $0.074 * * *$ \\
\hline & $(0.011)$ & $(0.027)$ & $(0.008)$ & $(0.019)$ & $(0.006)$ & $(0.015)$ \\
\hline \multirow[t]{2}{*}{ NewExp*dgap } & & -0.000 & & -0.000 & & -0.000 \\
\hline & & $(0.001)$ & & $(0.000)$ & & $(0.000)$ \\
\hline \multirow[t]{2}{*}{ NewExp*dat } & & -0.001 & & -0.010 & & -0.004 \\
\hline & & $(0.008)$ & & $(0.006)$ & & $(0.006)$ \\
\hline \multirow[t]{2}{*}{ Constant } & $3.689 * * *$ & $3.766^{* * *}$ & $3.685 * * *$ & $3.726 * * *$ & $3.704 * * *$ & $3.735 * * *$ \\
\hline & 0.006 & 0.025 & $0.034 * * *$ & $0.080 * * *$ & $0.034^{* * *}$ & $0.074 * * *$ \\
\hline HS 6digit FE & Yes & Yes & Yes & Yes & Yes & Yes \\
\hline Ownership FE & No & Yes & No & Yes & No & Yes \\
\hline $\mathrm{N}$ & 12963 & 12963 & 27682 & 27682 & 61282 & 61282 \\
\hline adj. R2 & 0.268 & 0.273 & 0.294 & 0.296 & 0.268 & 0.271 \\
\hline
\end{tabular}

